\title{
EFFECT OF SOME FLOOD IRRIGATION AND POTASSIUM FERTILIZATION TREATMENTS ON VEGETATIVE GROWTH, YIELD AND FRUIT QUALITY OF “DESSERT RED” PEACH TREES GROWN IN CLAY SOIL \\ Mikhael, G. B.Y.*; Manal A. Aziz** and W. M. Abd El-Messeih* \\ * Deciduous Fruit Trees Res. Dept., Hort. Res. Inst., ARC, Giza, Egypt \\ ** Soil, Water and Environ. Res. Inst., ARC, Giza, Egypt.
}

\section{ABSTRACT}

This investigation was carried out during 2008 and 2009 seasons to study the effect of three irrigation regimes at 80,70 and $60 \%$ of field capacity (FC) $\left(I_{1}, I_{2}\right.$ and $\left.I_{3}\right)$ and three potassium fertilizer levels at $0.5,0.75$ and $1 \mathrm{~kg} \mathrm{~K}_{2} \mathrm{SO}_{4}\left(48 \% \mathrm{~K}_{2} \mathrm{O}\right) /$ tree $\left(\mathrm{K}_{1}\right.$, $\mathrm{K}_{2}$ and $\mathrm{K}_{3}$ ), as well as, their interaction on vegetative growth, nutritional status, water relations, yield and fruit quality in addition to field water use efficiency (FWUE) of "Dessert Red" peach trees budded on Nemaguard rootstock grown in Sedy Salem District, Kafrelsheikh governorate. The obtained data indicated that, deficit irrigation regime was associated with reduced shoot length and diameter, number of leaves/shoot, area per leaf, shoot and leaf dry weights and trunk cross section areaincrease. However, increasing $\mathrm{K}$ fertilizer level caused a significant increase in previous vegetative growth characeristics. The application of $\left(\mathrm{I}_{1} \times \mathrm{K}_{3}\right)$ and/or $\left(\mathrm{I}_{2} \times \mathrm{K}_{3}\right)$ considered the best combination treatments for enhanced vegetative growth in both seasons of study.

In the two experimental seasons, reducing irrigation rate up to $60 \% \mathrm{FC}$ led to significant reduction in leaf macro and micro-nutrients, total chlorophyll contents, and significant increment in leaf free proline content. Meanwhile, increasing $\mathrm{K}$ fertilizer level from 0.5 to 0.75 or $1 \mathrm{~kg} \mathrm{~K}_{2} \mathrm{SO}_{4}$ /tree significantly increased leaf $\mathrm{K}$ and free proline contents but significantly reduced leaf $\mathrm{Ca}, \mathrm{Mg}$ and total chlorophyll contents. On the other hand, leaf $\mathrm{N}, \mathrm{P}, \mathrm{Fe}, \mathrm{Mn}$ and $\mathrm{Zn}$-contents were not affected by increasing the level of $\mathrm{K}$ fertilizer. Either deficit irrigation regime or high $\mathrm{K}$ fertilizer level recorded the highest values of bound water and osmotic pressure of cell sap and the lowest total and free water contents in both seasons.

Additionally, fruit yield ( $\mathrm{kg} / \mathrm{tree})$, yield efficiency $\left(\mathrm{kg} / \mathrm{cm}^{2} \mathrm{TCSA}\right)$ and total yield (ton/fed.) as well as average fruit weight, length and diameter were significantly increased by increasing either irrigation or $\mathrm{K}$ fertilizer levels, while, fruit firmness was reduced. Moreover, colour\%, skin anthocyanin content and SSC were significantly increased under high $\mathrm{K}$ fertilizer level but, significantly decreased under higher irrigation level. However, total acidity was not affected with the both tested irrigation and $\mathrm{K}$ fertilizer levels and their interaction in both seasons. Greatest yield with heaviest and largest fruit beside highest values of field water use efficiency (FWUE) were produced by applying $\left(\mathrm{I}_{1} \times \mathrm{K}_{3}\right)$ and/or $\left(\mathrm{I}_{2} \times \mathrm{K}_{3}\right)$ combination treatments.

Thus, this study recommend "Dessert Red" peach growers in clay soil to irrigate when soil moisture content reached $70 \%$ (FC) and to apply $1 \mathrm{~kg} \mathrm{~K}_{2} \mathrm{SO}_{4}(48 \%$ $\left.\mathrm{K}_{2} \mathrm{O}\right)$ /tree in $\left(\mathrm{I}_{2} \times \mathrm{K}_{3}\right)$ combination treatment which is considered the best one in this study. This treatment is not only stimulated vegetative growth and improved nutritional status and water relations but also produced maximum yield with high fruit quality especially fruit weight, size, colour and SSC content beside, saving irrigation water and increasing FWUE $\mathrm{kg} / \mathrm{m}^{3}$. 


\section{INTRODUCTION}

Peach is one of the most important deciduous fruit trees grown in Egypt. The total planted area increased rapidly through the last three decades. It reached about (100623) feddans and total annual production (399416) tons of fruits according to MALR (2008). "Dessert Red" is considered one of the leading peach cultivars in Egypt because of it needs low chilling requirements, it matures at the third week of May under Egyptian conditions.

In Egypt, although, the quantity of irrigation water is available, the ideal use of this water is essential. This minimizing water use not only reduce production cost but also help to meet the environmental regulation due to reduce the leaching of nutrients into ground water (Hanks, 1983). Soil moisture content is one of the main factors that most likely affect water in plant tissues. Under optimum level of soil moisture content, water distribution in plant tissues occurs at level very suitable for growth, development and fruiting (Mills et al., 1996 and Mpelasoka et al., 2001). Moreover, fruit size is a major criterion of peach fruit quality. Since fruit thinning and irrigation are considered the two agricultural practices that affected fruit size (Berman and Dejony, 1996 and Naor et al., 2001).

Numerous studies have shown that peach fruit size at harvest is not affected by drought during the early phases of fruit growth, but fruit size decreased when drought occurs during the main period of cell enlargement (Chalmers et al., 1985 and Li et al., 1989).

Potassium is the key in plant nutrition for promoting root growth and tree vigour, increasing yield and improving fruit quality as well as enhancing plant resistance to drought, salinity pests and diseases (Mengel and Kirkby, 1978). In addition, peach trees grown in North Nile Delta region, where the soil is slightly alkaline producing small and poor coloured fruits. In such type of soil depressing of potassium uptake is a nutritional problem, especially after building High Dam. Thus, soil application of potassium increased productivity and improved fruit quality of peach trees (Cummings, 1980 and Mansour et al., 1986) as well as increased plant drought resistance through an increase in its osmotic pressure (Grigorenko, 1973).

The present work was planned to study the possible effects of three irrigation regimes, three levels of potassium fertilizer and their interaction on vegetative growth, nutritional status, water relationships, yield and fruit quality as well as field water use efficiency of "Dessert Red" peach trees budded on Nemaguard rootstock grown in clay soil.

\section{MATERIALS AND METHODS}

This investigation was carried out during the two successive seasons of 2008 and 2009 on seven years "Dessert Red" peach trees (Prunus persica L. Batch) budded on nemaguard rootstock, spaced at $4 \times 4$ meters and grown in private orchard located at Sedy Salem District, Kafrelsheikh governorate, Egypt. The trees were subjected to cultural practices usually done in this 
area. The orchard soil is classified as clay and slightly alkaline $(\mathrm{pH}=8.2)$ and the water table was about $140-160 \mathrm{~cm}$. Some chemical and physical properties of the experimental soil are presented in Table (1). Soil moisture constant for the experimental site is illustrated in Table (2) according to the standard methods described by Black (1983) and Klute (1986).

Table (1):Some chemical and physical properties of the experimental soil

\begin{tabular}{|c|c|c|}
\hline Soil variable & & \\
\hline & $0-30$ & $30-60$ \\
\hline $\mathrm{pH}$ & 8.2 & 8.1 \\
\hline $\mathrm{EC}(\mathrm{dS} / \mathrm{m})$ & 3.26 & 2.82 \\
\hline SAR & 9.50 & 9.22 \\
\hline OM\% & 1.96 & 1.53 \\
\hline $\mathrm{CaCO}_{3} \%$ & 3.55 & 3.71 \\
\hline Porosity \% & 53.86 & 49.59 \\
\hline & ons (me & \\
\hline $\mathrm{Na}^{+}$ & 22.15 & 19.17 \\
\hline $\mathrm{K}^{+}$ & 0.36 & 0.29 \\
\hline $\mathrm{Ca}^{++}$ & 6.85 & 5.93 \\
\hline $\mathrm{Mg}^{++}$ & 3.92 & 3.41 \\
\hline & ns (me & \\
\hline $\mathrm{Cl}^{-}$ & 15.52 & 13.27 \\
\hline $\mathrm{HCO}_{3}{ }^{-}$ & 5.67 & 5.18 \\
\hline $\mathrm{CO}_{3}^{--}$ & 0.00 & 0.00 \\
\hline $\mathrm{SO}_{4}^{--}$ & 12.09 & 10.30 \\
\hline & distrib & \\
\hline Sand & 19.40 & 21.70 \\
\hline & 24.30 & 20.10 \\
\hline Clay & 56.30 & 58.20 \\
\hline Textural grade & Clay & Clay \\
\hline
\end{tabular}

OM=organic matter

Table (2):Soil moisture constant for the experimental site

\begin{tabular}{|l|c|c|c|c|}
\hline $\begin{array}{l}\text { Soil depth } \\
\text { (cm) }\end{array}$ & $\begin{array}{c}\text { Field capacity } \\
\text { (\%) }\end{array}$ & $\begin{array}{c}\text { Wilting point } \\
\text { (\%) }\end{array}$ & $\begin{array}{c}\text { Available water } \\
\text { (\%) }\end{array}$ & $\begin{array}{c}\text { Bulk density } \\
\left(\mathbf{g} / \mathbf{c m}^{\mathbf{3}} \text { ) }\right.\end{array}$ \\
\hline $0-15$ & 45.51 & 24.47 & 21.04 & 1.15 \\
$15-30$ & 40.62 & 21.16 & 19.46 & 1.27 \\
$30-45$ & 37.90 & 19.33 & 18.57 & 1.32 \\
$45-60$ & 35.97 & 18.84 & 17.13 & 1.39 \\
\hline Average & 40.00 & 20.95 & 19.05 & 1.28 \\
\hline
\end{tabular}

The experiments was designed as split plot in complete randomized blocks. Three irrigation regimes, $I_{1}, I_{2}$ and $I_{3}$ (irrigated at 80,70 and $60 \%$ of field capacity) were allocated in the main plots, while three potassium fertilization levels in the form of potassium sulphate $\left(48 \% \mathrm{~K}_{2} \mathrm{O}\right), \mathrm{K}_{1}, \mathrm{~K}_{2}$ and $\mathrm{K}_{3}$ at $0.5,0.75$ and $1 \mathrm{~kg} \mathrm{~K}_{2} \mathrm{SO}_{4} /$ tree/season, respectively were assigned to subplots in nine combination treatments ( 3 irrigation regimes $\times 3 \mathrm{~K}$-levels) including the control $\left(I_{1} \times K_{1}\right)$. Each treatment replicated three times with three trees in each replicate ( 3 replicates $\times 3$ trees). Thus 81 uniform trees were selected and used in this study.

Amount of irrigation water applied (Wa) for each treatment was determined according to soil moisture content in soil samples taken from consecutive depth of $15 \mathrm{~cm}$ down to a depth of $60 \mathrm{~cm}$ even before irrigation 
(at 80,70 and $60 \% \mathrm{FC}$ ) to reach its field capacity with 4128,3483 and 3096 $\mathrm{m}^{3} / \mathrm{fed}$./season distributed on 16, 9 and 6 irrigations, respectively as shown in Table (3). Submerged flow orifice with fixed dimension was used to measure the amount of water applied as the following equation (Michael, 1978).

$$
\mathrm{Q}=\mathrm{CA} \sqrt{2 \mathrm{gh}}
$$

Where:

$\mathrm{Q}=$ Discharge through orifice (L/sec.).

$\mathrm{C}=$ Coefficient of discharge $(0.61)$

$\mathrm{A}=$ Cross section area of the orifice, $\mathrm{m}^{2}$

$\mathrm{g}=$ acceleration due to gravity, $\mathrm{cm} / \mathrm{sec}^{2}\left(981 \mathrm{~cm} / \mathrm{sec}^{2}\right)$

$\mathrm{h}=$ Pressure head, causing discharge through the orifice, $\mathrm{cm}$.

Table (3):The quantity of irrigation water applied $\left(\mathrm{m}^{3} / \mathrm{fed}\right.$ ) in the different irrigation treatments during each growing season.

\begin{tabular}{|l|c|c|c|c|}
\hline $\begin{array}{l}\text { Irrigation } \\
\text { treatments }\end{array}$ & \multirow{2}{*}{ No. of irrigations } & \multicolumn{2}{|c|}{\begin{tabular}{c} 
Amount of each irrigation water \\
\cline { 3 - 5 }
\end{tabular}} & $\begin{array}{c}\text { Water applied (Wa) } \\
\mathbf{m}^{\mathbf{3}} / \mathbf{f e d} / \mathbf{s e a s} \text { ( }\end{array}$ \\
\hline $80 \%$ FC & 16 & 6.144 & 258 & 4128 \\
$70 \%$ FC & 9 & 9.212 & 387 & 3483 \\
$60 \%$ FC & 6 & 12.288 & 516 & 3096 \\
\hline
\end{tabular}

Each level of potassium fertilizer was divided into two equal doses and added in March and April. N and $\mathrm{P}$ fertilizers were added at constant rate for experimental trees [1.25 kg ammonium nitrate $(33.5 \% \mathrm{~N})+1.5 \mathrm{~kg}$ calcium superphosphate $\left(15.5 \% \mathrm{P}_{2} \mathrm{O}_{5}\right) /$ tree/season]. Beside, $10 \mathrm{~m}^{3} / \mathrm{fed}$. farmyard manure as organic fertilizer in winter service.

\section{Measurements and Determinations:}

\section{a. Vegetative growth characteristics:}

Four branches in different directions on each tree were labeled. All current shoots developed on these branches in spring were used for measuring vegetative growth characteristics, i.e. shoot length and diameter $(\mathrm{cm})$ and number of leaves/shoot. Four shoots (one shoot per direction) were sampled and all leaves were measured by Li-core 3100 Areameter to get area per leaf $\left(\mathrm{cm}^{2}\right)$. Shoot and leaf samples were oven dried at $70^{\circ} \mathrm{C}$ and weighed to get shoot and leaf dry weights $(\mathrm{g})$, then leaf specific weight (L.S.W) was calculated as $\mathrm{mg} / \mathrm{cm}^{2}$ according to Hunt (1989), also seasonal increment in trunk cross sectionn area (TCSA) $\mathrm{cm}^{2}$ was calculated.

\section{b. Chemical determinations:}

Thirty mature mid-shoot leaves in mid-June of both seasons were sampled to determine leaf mineral content. Nitrogen was estimated by micro-kjeldahl gunning method (A.O.A.C., 1990). Phosphorus was determined with a colourimetric method as described by Foster and Cornelia (1967). Potassium was determined by a flame photometer model E.E.L. (Jackson, 1967). Calcium, magnesium, iron, zinc and manganese were determined by Perking-Elmer Atomic absorption spectrophotometer model 2380 AL, according to Jackson and Ulish (1959) and Yoshida et al. (1972).

Leaf total chlorophyll content (SPAD unit) values was determined by using portable Minolta Chlorophyll Meter (Model SPAD-501). Leaf sample 
collected in mid-June and the reading was taken at the middle of leaf blade according to Murquard and Timpton (1987).

Fully expanded leaves were sampled in first of August in 2008 and 2009 seasons. Approximately $0.5 \mathrm{~g}$ of fresh leaf samples was homogenized in $10 \mathrm{ml}$ of $3 \%$ sulphosalicylic acid and the homogenate filtered through Whatman No. 2 filter paper, then the proline was extracted in the filtrate using acid non-hydrine and galical acetic acid. The absorbency of the supernatant was recorded using spectrophotometer at $520 \mathrm{~nm}$ wave length and the concentration was estimated from standard curve as $\mu \mathrm{mole} / \mathrm{g}$ fresh weight according to Bates et al. (1973).

c. Water relation determinations:

Leaf sample were taken before irrigation for analysis, the samples were collected usually at sunrise and taken to laboratory in well tight plastic bags wrapped with moist cloth sheet. These prepared samples were used for the determination of total water and free water contents, then bound water content was calculated as the difference between total and free water content. Beside, cell sap concentration was estimated using a hand refractometer and the corresponding values of osmotic pressure were determined according to the method described by Gosev (1960) as modified by Koshirinko et al. (1970).

d. Yield and fruit quality:

At harvest time (May 18 th and May 16 $6^{\text {th }}$ ) in 2008 and 2009 seasons, respectively yield as fruit weight $(\mathrm{kg})$ per tree, yield efficiency $(\mathrm{YE}) \mathrm{kg} \mathrm{per} \mathrm{cm}^{2}$ TCSA and yield (ton/fed) were estimated. Ten mature fruits were collected at random to determine fruit weight $(\mathrm{g})$, dimensions $(\mathrm{cm})$, fruit firmness $\left(\mathrm{lb} / \mathrm{in}^{2}\right)$ and skin colour \% visually. Juice samples were prepared to determine total soluble solids (SSC) by using galliles hand refractometer and total titratable acidity \% as malic acid according to A.O.A.C. (1990). Anthocyanin pigment content in fruit skin $\mu \mathrm{g} / \mathrm{cm}^{2}$ were determined colourimetrically according to Ranganna (1979). Field water use efficiency (FWUE) $\mathrm{kg} / \mathrm{m}^{3}$ was calculated according to Michael (1978) by the following equation:

$$
\text { FWUE }\left(\mathrm{kg} / \mathrm{m}^{3}\right)=\frac{\text { yield }(\mathrm{kg} / \mathrm{fed} .)}{\text { water applied }\left(\mathrm{m}^{3} / \mathrm{fed}\right)}
$$

The obtained data were subjected to statistical analysis according to Snedecor and Cochran (1990) and LSD test at 0.05 level were used for comparing between averages.

\section{RESULTS AND DISCUSSION}

Effect of irrigation regime (I), potassium fertilizer level $(K)$ and their interaction ( $\mathrm{X} \mathrm{K}$ ) on:

1. Vegetative growth characteristics:

a. Shoot and leaf growth characteristics:

Obtained data in Table (4) and Fig. (1) revealed that, shoot and leaf growth parameters of "Dessert Red" peach trees except for leaf specific weight $\left(\mathrm{mg} / \mathrm{cm}^{2}\right)$ were significantly affected by irrigation regimes, potassium 
fertilizer levels and their interaction in 2008 and 2009 seasons. The highest values of shoot length, diameter, shoot and leaf dry weights and area per leaf and the highest number of leaves/shoot were obtained from trees irrigated at $80 \%$ FC $\left(\mathrm{l}_{1}\right)$, while the lowest values in this respect were found by trees subjected to deficit irrigation rate $60 \% \mathrm{FC}\left(\mathrm{I}_{3}\right)$. This reduction in tree growth under water stress conditions could be due to lower photosynthetic rate and stomatal conductance (Mpelascoka et al., 2001). In addition, Atkinson et al. (2000) indicated that drought stress induced an increase in root abcisic acid (ABA) production and transportation to the shoot. The increase in ABA could be expected to reduce shoot growth and leaf expansion of "Queen Cox" apple trees. The above mentioned results are in accordance with those reported by Boland et al. (2000) on peach trees, Abd El-Messeih and ElGendy (2004a) on "Canino" apricot trees, Mikhael (2007) on "Anna" apple trees and Ibrahim and Abd El-Samad (2009) on "Manfalouty" pomegranate trees. They found that shoot and leaf growth were significantly reduced under the low irrigation rate.

Table (4):Effect of irrigation and potassium fertilizer level and their interaction on vegetative growth of "Dessert Red" peach trees in 2008 and 2009 seasons.

\begin{tabular}{|c|c|c|c|c|c|c|c|c|c|c|c|c|c|}
\hline \multirow{2}{*}{\multicolumn{2}{|c|}{\begin{tabular}{|l|l|}
\multicolumn{2}{|l}{ Treatments } \\
Irrigation & Fertilization \\
(I) levels & (K) levels \\
\end{tabular}}} & \multicolumn{2}{|c|}{$\begin{array}{c}\text { Av. shoot } \\
\text { length } \\
\text { (cm) }\end{array}$} & \multicolumn{2}{|c|}{$\begin{array}{l}\text { Av. shoot } \\
\text { diameter } \\
\text { (cm) }\end{array}$} & \multicolumn{2}{|c|}{$\begin{array}{c}\text { No. of } \\
\text { leaves/ } \\
\text { shoot }\end{array}$} & \multicolumn{2}{|c|}{$\begin{array}{c}\text { Area per } \\
\text { leaf } \\
\left(\mathrm{cm}^{2}\right)\end{array}$} & \multicolumn{2}{|c|}{$\begin{array}{l}\text { Leaf dry } \\
\text { weight } \\
\text { (g/leaf) }\end{array}$} & \multicolumn{2}{|c|}{\begin{tabular}{|c|} 
L.S.W. \\
$\left(\mathrm{mg} / \mathrm{cm}^{*}\right)$
\end{tabular}} \\
\hline & & 2008 & 2009 & 2008 & 2009 & 2008 & 2009 & 2008 & 2009 & 2008 & 2009 & 2008 & 2009 \\
\hline & $\mathrm{K}_{1}$ & 32.5 & 34.7 & 0.33 & 0.35 & 26.6 & 27.3 & 30.81 & 32.16 & 0.206 & 0.201 & 6.68 & 6.25 \\
\hline \multirow[t]{2}{*}{$I_{1}$} & & 39.8 & 40.6 & 0.37 & 0.39 & 31.6 & 32.5 & |33.34 & 27 & 0.221 & 0.232 & 6.63 & 6.18 \\
\hline & & 42.4 & 43.4 & 0.39 & 0.41 & 34.7 & 34.5 & & & 0.234 & 0.246 & 6.94 & \\
\hline \multicolumn{2}{|l|}{ Average } & 38.2 & 39.6 & \begin{tabular}{|l|}
0.36 \\
\end{tabular} & 0.38 & 31.0 & 31.4 & 33.15 & 34.47 & 0.220 & \begin{tabular}{|l|}
0.226 \\
\end{tabular} & 6.75 & 6.56 \\
\hline \multirow{3}{*}{$I_{2}$} & $K_{1}$ & 27.6 & 28.5 & 0.30 & 0.31 & 22.1 & 23.2 & 25.70 & 27.13 & 0.180 & 0.185 & 6.99 & 6.83 \\
\hline & K & 35.4 & 36.3 & 0.36 & 0.37 & 26.9 & 27.8 & 30.21 & 31.04 & 0.192 & 0.211 & 6.37 & 6.81 \\
\hline & $x_{-1}$ & 40.8 & 41.3 & 0.38 & 0.40 & 31.3 & 31.5 & 33.62 & 34.59 & 0.247 & 0.235 & 7.36 & 6.79 \\
\hline \multicolumn{2}{|l|}{ Average } & 34.6 & 35.4 & 0.35 & 0.36 & 26.8 & 27.5 & 29.84 & 30.92 & 0.206 & 0.210 & 6.91 & 6.81 \\
\hline \multirow{3}{*}{$I_{3}$} & $\mathrm{~K}_{1}$ & 22.1 & 21.9 & \begin{tabular}{|l|}
0.27 \\
\end{tabular} & 0.29 & 18.9 & \begin{tabular}{|l|}
19.1 \\
\end{tabular} & 18.32 & 20.61 & 0.121 & \begin{tabular}{|l|}
0.133 \\
\end{tabular} & 6.61 & 6.44 \\
\hline & $\mathrm{K}_{2}$ & 28.8 & 29.2 & 0.31 & 0.34 & 23.3 & 24.4 & 22.18 & & 0.166 & 0.156 & 7.48 & 6.72 \\
\hline & $K_{3}$ & 31.6 & 32.1 & 0.34 & 0.36 & 25.5 & 25.8 & 28.06 & 28.78 & 0.191 & 0.212 & 6.80 & 7.36 \\
\hline \multicolumn{2}{|l|}{ Average } & 27.5 & 27.7 & 0.31 & 0.33 & 22.6 & 23.1 & 22.85 & 24.21 & 0.159 & 0.167 & 6.96 & 6.84 \\
\hline \multirow{3}{*}{ Average } & $\mathrm{K}_{1}$ & 27.4 & 28.4 & 0.30 & 0.32 & 22.5 & 23.2 & 24.94 & 26.63 & 0.169 & \begin{tabular}{|l|}
0.173 \\
\end{tabular} & 6.76 & 6.51 \\
\hline & $K_{2}$ & 34.7 & 35.4 & 0.35 & 0.37 & 27.3 & 28.2 & 28.58 & 29.52 & 0.193 & 0.200 & 6.83 & 6.77 \\
\hline & $K_{3}$ & 38.3 & 38.9 & 0.37 & 0.39 & 30.5 & 30.6 & 32.32 & 33.45 & 0.224 & 0.231 & 7.03 & 6.93 \\
\hline \multirow{3}{*}{ L.S.D5\% } & t & 2.57 & 2.17 & 0.013 & 0.015 & 2.30 & 1.99 & 4.134 & $3.261 \mid$ & 0.0142 & 0.0131 & NS & NS \\
\hline & K & 2.34 & 1.51 & 0.010 & 0.014 & 2.54 & 1.02 & 3.241 & 2.570 & 0.0272 & 0.0324 & NS & NS \\
\hline & $1 \times K$ & 4.05 & 2.77 & 0.018 & 0.024 & 4.39 & 1.77 & 5.644 & 4.451 & 0.0471 & 0.0562 & NS & NS \\
\hline
\end{tabular}

Regarding the effect of potassium fertilization, the data exhibit gradual increase in shoot length and diameter $(\mathrm{cm})$, shoot and leaf dry weight $(\mathrm{g})$, leaf area per leaf $\left(\mathrm{cm}^{2}\right)$ and number of leaves/shoot by increasing the level of potassium fertilizer from 0.5 up to 0.75 or $1 \mathrm{~kg} \mathrm{~K}_{2} \mathrm{SO}_{4} /$ tree. This improvement in vegetative growth characteristics could be attributed to the rate of $\mathrm{K}$ element which enhanced the net of photosynthesis $(\mathrm{Pn})$ and 
increased the formation and translocation of the photosynthetic products. Such findings are in agreement with those reported by El-Morshedy (1997) on "Early grand" peach trees, Zayan et al. (2006) on "Thompson seedless" grapevines and Gowda (2007) on "Sultani" fig trees. They indicated that, soil potassium application enhanced different shoot and leaf growth characteristics. However, the most important data were disclosed by the interaction $(\mathrm{I} \times \mathrm{K})$ which was significant in both seasons. The highest values of previous vegetative growth characteristics were obtained with $\left(\mathrm{I}_{1} \times \mathrm{K}_{3}\right)$ and $\left(\mathrm{I}_{2} \times \mathrm{K}_{3}\right)$ combination treatments without significant differences between them in both seasons and differences between each of them and other treatments was significant. While, the least values belonged to $\left(\mathrm{I}_{3} \times \mathrm{K}_{1}\right)$ treatment.

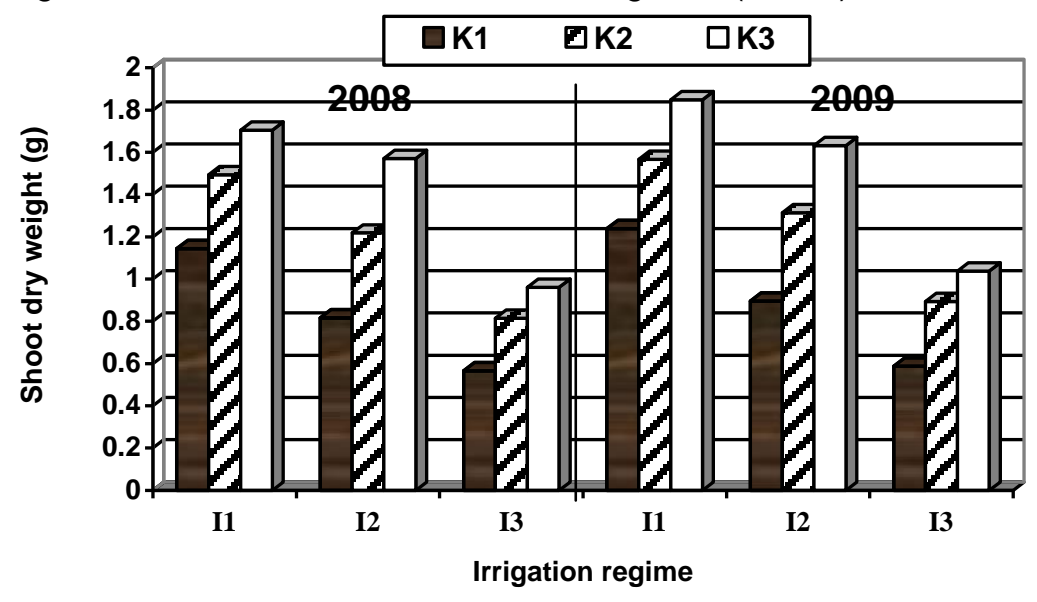

Fig. (1): Effect of irrigation and potassium fertilizer levels on shoot dry weight $(\mathrm{g})$ of "Dessert Red" peach trees in 2008 and 2009 seasons.

b. Trunk cross section area (TCSA)-increase $\left(\mathrm{cm}^{2}\right)$

Data of both seasons illustrated in Fig. (2) showed that TCSAincrease $\left(\mathrm{cm}^{2}\right)$ of "Dessert Red" peach trees take the same trend as shoot and leaf growth characteristics as affected with irrigation regimes and potassium fertilizer levels, as well as their interaction. The most effective combination treatments were $\left(\mathrm{I}_{1} \times \mathrm{K}_{3}\right)$ and/or $\left(\mathrm{I}_{2} \times \mathrm{K}_{3}\right)$ which recorded the largest TCSA-increase $\left(\mathrm{cm}^{2}\right)$ while the minimum values came from $\left(\mathrm{I}_{3} \times \mathrm{K}_{1}\right)$. The other treatment gave the intermediate values. Moreover, the highest values of TCSA-increase $\left(\mathrm{cm}^{2}\right)$ were obtained from tree that irrigated at $80 \%$ F.C. These results are in harmony with those reported by Shahein et al. (2002a), Mikhael (2007) and Ibrahim and Abd El-Samad (2009) who mentioned that, higher rate of irrigation induced significantly higher TCSAincrease due to the improvement in shoot growth and leaf expansion. Meanwhile, adding high level of potassium fertilizer (1 $\mathrm{kg} \mathrm{K}_{2} \mathrm{SO}_{4} /$ tree) markedly increased TCSA-increase $\left(\mathrm{cm}^{2}\right)$. Similar response were reported by Gowda (2007) on "Sultani" fig trees. 
Conclusively, irrigation at $70 \% \mathrm{CF}$ under soil application with $1 \mathrm{~kg}$ potassium sulphate $\left(48 \% \quad \mathrm{~K}_{2} \mathrm{O}\right)$ in $\left(\mathrm{I}_{2} \times \mathrm{K}_{3}\right)$ considered the suitable combination treatments for improving vegetative growth of "Dessert Red" peach trees grown in clay soil due to saving irrigation water by using moderate rate $\left(\mathrm{I}_{2}\right)$.

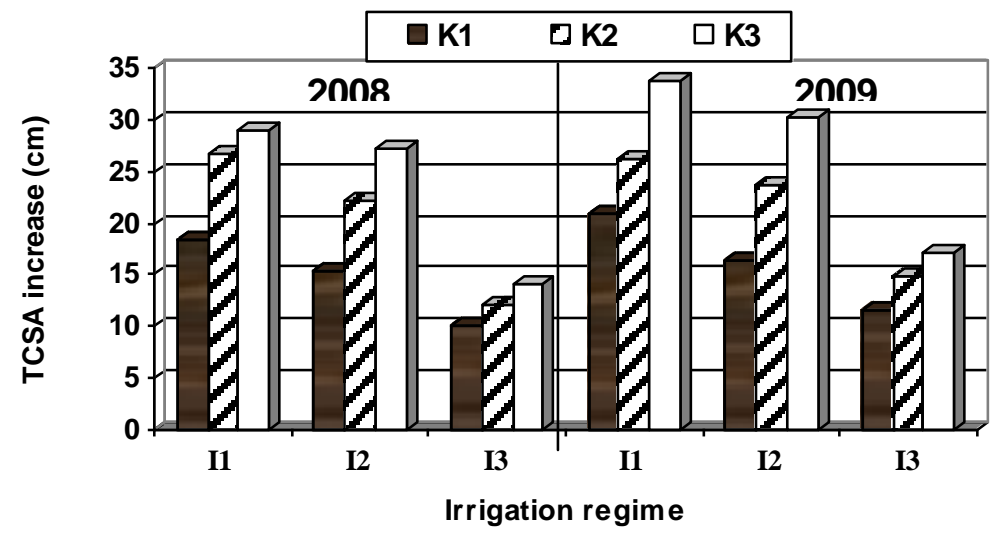

Fig. (2): Effect of irrigation and potassium fertilizer levels on TCSAincrease of "Dessert Red" peach trees in 2008 and 2009 seasons.

\section{Nutritional status:}

\section{a. Leaf mineral content:}

Data of macro and micro nutrients as affected by irrigation regimes potassium fertilizer levels and their interaction are presented in Tables ( 5 and $6)$.

Concerning, the influence of irrigation regimes, it is clear that, reduced irrigation rate significantly decreased leaf $\mathrm{N}, \mathrm{P}, \mathrm{K}, \mathrm{Ca}, \mathrm{Mg}, \mathrm{Fe}, \mathrm{Mn}$ and $\mathrm{Zn}$-contents and the differences among the three tested irrigation rates were significant in 2008 and 2009, seasons. These results could be led to a conclusion that nutrients uptake was retarded under water stress conditions, where the root failed to absorb the accumulative valuable nutrient elements. Moreover, depletion of soil moisture level caused a reduction in leaf mineral contents due to reduced active rooting as an indirect influence (Abd ElMesseih and El-Gendy, 2004b). These results confirmed those reported by many previous investigators such as Nandwal et al. (1996), Hussein (1998), Fathi et al. (1999) and Mikhael (2007). They concluded that, leaf mineral content significantly declined under drought conditions.

According to leaf analysis presented in Table ( 5 and 6 ), it is clear that, leaf $\mathrm{K}$ content was significantly increased while, leaf $\mathrm{Ca}$ and $\mathrm{Mg}$ were significantly reduced under soil application with high level of potassium ( $1 \mathrm{~kg} \mathrm{~K}_{2} \mathrm{SO}_{4} /$ tree $)$. However, $\mathrm{K}$ application levels insignificantly affected leaf $\mathrm{N}, \mathrm{P}, \mathrm{Fe}, \mathrm{Mn}$ and $\mathrm{Zn}$ contents. This hold was true in both seasons. The reduction attributed in leaf $\mathrm{Ca}$ and $\mathrm{Mg}$ contents in response to adding $\mathrm{K}$ fertilizer might be due to the antagonism effect. These results were supported by those obtained by 
Mikhael (1994), El-Morshedy (1997), Abo Ogiela (2006), Gowda (2007) and Moawad (2008) on different fruit trees.

As for the interaction, the data revealed that, the interaction $(\mathrm{I} \times \mathrm{K})$ was significant in the two seasons of study and the highest values of leaf macro and micro nutrients belonged to the control $\left(\mathrm{I}_{1} \times \mathrm{K}_{1}\right),\left(\mathrm{I}_{1} \times \mathrm{K}_{2}\right)$ and $\left(\mathrm{I}_{1} \times\right.$ $\mathrm{K}_{3}$ ) treatments and the differences among them were insignificant.

Table (5): Effect of irrigation and potassium fertilizer levels and their interaction on leaf macronutrients of "Dessert Red" peach trees in 2008 and 2009 seasons.

\begin{tabular}{|c|c|c|c|c|c|c|c|c|c|c|c|}
\hline \multirow{3}{*}{\multicolumn{2}{|c|}{\begin{tabular}{|l|l|}
\multicolumn{2}{|l|}{ Treatments } \\
Irrigation Fertilization \\
(I) levels & (K) levels \\
\end{tabular}}} & \multicolumn{10}{|c|}{ Macronutrients (\%) on DWt. } \\
\hline & & \multicolumn{2}{|c|}{$\mathbf{N}$} & \multicolumn{2}{|c|}{$\mathbf{P}$} & \multicolumn{2}{|c|}{$\mathrm{K}$} & \multicolumn{2}{|c|}{$\mathbf{C a}$} & \multicolumn{2}{|c|}{ Mg } \\
\hline & & 2008 & 2009 & 2008 & 2009 & 2008 & 2009 & 2008 & 2009 & 2008 & 2009 \\
\hline \multirow{3}{*}{$l_{1}$} & $\mathrm{~K}_{1}$ & 2.59 & 2.55 & 0.37 & 0.35 & 1.62 & 1.71 & 1.42 & 1.39 & 0.45 & 0.47 \\
\hline & $\mathrm{K}_{2}$ & 2.57 & 2.56 & 0.36 & 0.33 & 1.79 & 1.83 & 1.36 & 1.33 & 0.42 & 0.45 \\
\hline & $\mathrm{K}_{3}$ & 2.53 & 2.48 & 0.32 & 0.30 & 1.87 & 1.89 & 1.33 & 1.30 & 0.36 & 0.38 \\
\hline \multicolumn{2}{|l|}{ Average } & 2.56 & 2.53 & 0.35 & 0.33 & 1.76 & 1.81 & 1.37 & 1.34 & 0.41 & 0.43 \\
\hline \multirow{3}{*}{$l_{2}$} & $\mathrm{~K}_{1}$ & 2.39 & 2.42 & 0.33 & 0.31 & 1.48 & 1.57 & 1.35 & 1.33 & 0.40 & 0.43 \\
\hline & $\mathrm{K}_{2}$ & 2.43 & 2.35 & 0.32 & 0.2 & 1.59 & 1.64 & 1.30 & 1.26 & 0.38 & 0.37 \\
\hline & $\mathrm{K}_{3}$ & 2.44 & 2.37 & 0.28 & 0.27 & 1.82 & 1.86 & 1.27 & 1.25 & 0.33 & 0.35 \\
\hline \multicolumn{2}{|c|}{ Average } & 2.42 & 2.38 & 0.31 & 0.29 & 1.63 & 1.69 & 1.31 & 1.28 & 0.37 & 0.38 \\
\hline \multirow{3}{*}{$1_{3}$} & $\mathrm{~K}_{1}$ & 2.22 & 2.15 & 0.26 & 0.24 & 1.28 & 1.31 & 1.28 & 1.22 & 0.35 & 0.36 \\
\hline & $\mathrm{K}_{2}$ & 2.14 & 2.13 & 0.25 & 0.23 & 1.34 & 1.36 & 1.24 & 1.20 & 0.32 & 0.34 \\
\hline & $\mathrm{K}_{3}$ & 2.12 & 2.09 & 0.21 & 0.19 & 1.55 & 1.59 & 1.17 & 1.15 & 0.24 & 0.26 \\
\hline \multicolumn{2}{|l|}{ Average } & 2.16 & 2.12 & 0.24 & 0.22 & 1.39 & 1.42 & 1.23 & 1.19 & 0.30 & 0.32 \\
\hline \multirow{3}{*}{ Average } & $\mathrm{K}_{1}$ & 2.40 & 2.37 & 0.32 & 0.30 & 1.46 & 1.53 & 1.35 & 1.31 & 0.40 & 0.42 \\
\hline & $\mathrm{K}_{2}$ & 2.38 & 2.35 & 0.31 & 0.28 & 1.57 & 1.61 & 1.30 & 1.26 & 0.37 & 0.39 \\
\hline & $\mathrm{K}_{3}$ & 2.36 & 2.31 & 0.27 & 0.25 & 1.75 & 1.78 & 1.26 & 1.23 & 0.31 & 0.33 \\
\hline \multirow{3}{*}{ L.S.D5\% } & 1 & 0.112 & 0.194 & 0.041 & 0.040 & 0.059 & 0.061 & 0.058 & 0.052 & 0.041 & 0.039 \\
\hline & $\mathrm{K}$ & NS & NS & NS & NS & 0.046 & 0.057 & 0.042 & 0.038 & 0.032 & 0.030 \\
\hline & $\mathrm{I} \times \mathrm{K}$ & 0.126 & 0.169 & 0.081 & 0.079 & 0.080 & 0.097 & 0.072 & 0.065 & 0.056 & 0.052 \\
\hline
\end{tabular}

$I_{1}, I_{2}$ and $I_{3}=$ Irrigation at 80,70 and $60 \%$ of field capacity (FC), respectively

$\mathrm{K}_{1}, \mathrm{~K}_{2}$ and $\mathrm{K}_{3}=0.5,0.75$ and $1 \mathrm{~kg}$ potassium sulphate $\left(48 \% \mathrm{~K}_{2} \mathrm{O}\right) /$ tree, respectively.

\section{b. Total leaf chlorophyll content:}

Data in Table (6) cleared that, total chlorophyll contents in leaves of "Dessert Red" peach trees was significantly higher under high irrigation regime $\left(I_{1}\right)$ followed by $\left(I_{2}\right)$ and $\left(I_{3}\right)$ with significant differences among them in the first season. Data of the second season showed the same trend. These results exhibit positive correlation between soil moisture level and total leaf chlorophyll content. This increment in total leaf chlorophyll content could be attributed to increase the uptake of macronutrients, especially $\mathrm{N}$ and $\mathrm{Mg}$ element via the root as consequence of improved soil moisture, whereas $\mathrm{N}$ and Mg nutrient are necessary for chlorophyll synthesis (Mengle and Kirkby, 1982). Data of macronutrient in Table (5) supported this explanation. Such results are in line with those obtained by Abd El-Messeih and El-Gendy (2004b) and Mikhaeil (2007). They found that, decreasing the amount of irrigation water caused a significant decrease in leaf total chlorophyll. Concerning the effect of addition of potassium, the data revealed significant reduction in total leaf chlorophyll content by increasing the level of potassium. The highest leaf chlorophyll value recorded with adding $0.5 \mathrm{~kg} \mathrm{~K}_{2} \mathrm{SO}_{4} /$ tree $\left(\mathrm{K}_{1}\right)$. This result might be due to the 
reduction in leaf $\mathrm{Mg}$ as consequence of increasing $\mathrm{K}$ level. These results coincided with those reported by Keleg et al. (1977) on almond, Kassem (1991) on apple and El-Morshedy (1997) on peach. They found that leaf chlorophyll value decreased as potassium fertilization. The interaction $(\mathrm{I} \times \mathrm{K})$ was significant in 2008 and 2009 seasons and the highest values of total leaf chlorophyll content recorded with the control $\left(l_{1} \times K_{1}\right)$ treatment, while the least values belonged to $\left(\mathrm{I}_{3} \times \mathrm{K}_{3}\right)$ interaction.

\section{c. Leaf free proline content:}

As shown in Table (6), it is clear that, leaf free proline content of "Dessert Red" peach trees was significantly higher under deficit irrigation treatment $\left(I_{3}\right)$ discendingly followed by $I_{2}$ and $I_{1}$. These results revealed negative correlation between soil moisture level and leaf free proline content. This result means that water stress under deficit irrigation condition led to increase hydrolysis of proteins and stimulate the biosynthesis and accumulation of free amino acid proline in leaves. These results are in harmony with those obtained by Zayan et al. (2002) on grapevines, ElSanhoury (2003) on apricot seedlings and Mikhael (2007) on apple trees. They reported that water stress is associated with wilting which cause an increase of non-protein proline formation.

Table (6):Effect of irrigation and potassium fertilizer levels and their interaction on leaf micronutrients, total chlorophyll and free proline contents of "Dessert Red" peach trees in 2008 and 2009 seasons.

\begin{tabular}{|c|c|c|c|c|c|c|c|c|c|c|c|}
\hline \multirow{3}{*}{\multicolumn{2}{|c|}{\begin{tabular}{|l|l|} 
Treatments \\
$\begin{array}{l}\text { Irrigation } \\
\text { (I) levels }\end{array}$ & $\begin{array}{l}\text { Fertilization } \\
\text { (K) levels }\end{array}$ \\
\end{tabular}}} & \multicolumn{6}{|c|}{ Micronutrients (ppm) } & \multirow{2}{*}{\multicolumn{2}{|c|}{$\begin{array}{l}\text { Total leaf } \\
\text { chlorophyll } \\
\text { (SPAD unit) }\end{array}$}} & \multirow{2}{*}{\multicolumn{2}{|c|}{$\begin{array}{l}\text { Free proline } \\
\mu \text { moles } / g \\
\text { fresh weight }\end{array}$}} \\
\hline & & \multicolumn{2}{|c|}{$\mathrm{Fe}$} & \multicolumn{2}{|c|}{ Mn } & \multicolumn{2}{|c|}{ Zn } & & & & \\
\hline & & 2008 & 2009 & 2008 & 2009 & 2008 & 2009 & 2008 & 2009 & 2008 & 2009 \\
\hline \multirow{3}{*}{$\mathrm{l}_{1}$} & $\mathrm{~K}_{1}$ & 153.5 & 151.9 & 59.8 & 58.2 & 20.9 & 21.8 & 45.9 & 46.3 & .25 & 0.28 \\
\hline & & .7 & 149.2 & 57.9 & $5 / .7$ & 20.6 & 21.7 & 44.7 & 45.9 & 7 & 0.31 \\
\hline & & 147.2 & 143.7 & 56. & 54.5 & 19. & 20.3 & 42.2 & 3.4 & 1 & 0.32 \\
\hline \multicolumn{2}{|l|}{ Average } & 151.8 & 148.3 & 58.1 & 56.8 & 20.3 & 21.3 & 44.3 & 45.2 & 28 & 0.30 \\
\hline \multirow{3}{*}{$l_{2}$} & $\mathrm{~K}_{1}$ & 139.4 & 138.6 & 57.3 & 55.1 & 19.0 & 20.5 & 43.2 & 43.7 & 0.30 & 0.33 \\
\hline & $\mathrm{K}_{2}$ & 140.4 & 136.3 & 55.6 & 53.7 & 19.3 & 19.8 & 42.9 & 42.8 & 5 & 0.36 \\
\hline & & 137.8 & 135.2 & 51.2 & 50.9 & 17.8 & 18.7 & 41.1 & 41.5 & 37 & 0.40 \\
\hline \multicolumn{2}{|l|}{ Average } & 139.2 & 136.7 & 54.7 & 53.2 & 18.7 & 19.7 & 42.4 & 42.8 & 0.34 & 0.36 \\
\hline \multirow{3}{*}{$\|_{3}$} & $\mathrm{~K}_{1}$ & 120.1 & 116.5 & 48.0 & 47.6 & 14.4 & 15.8 & 39.5 & 40.2 & .41 & 0.44 \\
\hline & $\mathrm{K}_{2}$ & 118.9 & $\mid 114.7$ & 47.1 & 44.8 & 14.9 & 16.3 & 38.9 & 39.9 & 0.46 & 0.47 \\
\hline & $k$ & 116.2 & 110.4 & 45.3 & 43.5 & 13.6 & 14.1 & 37.6 & 37.9 & 0.49 & 0.51 \\
\hline \multicolumn{2}{|l|}{ Average } & 118.4 & 113.9 & 46.8 & 45.3 & 14.3 & 15.4 & 38.7 & 39.3 & 0.45 & 0.47 \\
\hline \multirow{3}{*}{ Average } & $\mathrm{K}_{1}$ & 137.7 & 135.7 & 55.0 & 53.6 & 18.1 & 19.4 & 42.7 & 43.4 & 0.32 & 0.35 \\
\hline & $\mathrm{K}_{2}$ & 138.0 & 133.4 & 53.5 & 52.1 & 18.3 & 19.3 & 42.2 & 42.9 & 0.36 & 0.38 \\
\hline & $K$ & 133.7 & 129.8 & 51.0 & 49.6 & 17.0 & 17.7 & 40.3 & 41.1 & 0.39 & 0.41 \\
\hline \multirow{3}{*}{ L.S.D5\% } & & 7.10 & 7.67 & 3.52 & 1.74 & 1.73 & 2.04 & 1.86 & 1.44 & 0.013 & 0.014 \\
\hline & K & NS & NS & NS & NS & NS & NS & 1.13 & 1.32 & 0.010 & 0.015 \\
\hline & $I \times K$ & 7.04 & 6.13 & 2.82 & 3.49 & 1.82 & 1.83 & 1.95 & 2.27 & 0.018 & 0.026 \\
\hline
\end{tabular}

$\mathrm{I}_{1}, \mathrm{I}_{2}$ and $\mathrm{I}_{3}=$ Irrigation at 80,70 and $60 \%$ of field capacity (FC), respectively

$\mathrm{K}_{1}, \mathrm{~K}_{2}$ and $\mathrm{K}_{3}=0.5,0.75$ and $1 \mathrm{~kg}$ potassium sulphate $\left(48 \% \mathrm{~K}_{2} \mathrm{O}\right) /$ tree, respectively. 
Data of Table (6) showed that, leaf proline content was significantly increased by raising the level of potassium fertilizer from $K_{1}$ to $K_{3}$. The differences among the three tested $\mathrm{K}$ levels were significant in both seasons. These results confirmed with those reported by El-Abd (2005) on "Washington Navel" orange trees who indicated that, leaf proline content tended to increase as consequence of increasing potassium doses. Concerning the effect of interaction $(\mathrm{I} \times \mathrm{K})$, the data of both seasons showed that, the low irrigation regime combined with high level of potassium $\left(I_{3} \times K_{3}\right)$ interaction recorded the highest leaf proline concentration.

\section{Water relations:}

\section{a. Total and free water contents:}

It is clear from the data of Table (7) that, total and free water contents in leaf tissues of "Dessert Red" peach trees were significantly decreased by reducing irrigation rate from 80 to $60 \% \mathrm{FC}$. Low irrigation regime recorded the least values and the differences were significant in 2008 and 2009 seasons. The reduction in the total and free water content under low irrigation rate $(60 \% \mathrm{FC})$ could be resulted from the reduction of water absorption via the roots. Similar results were obtained by Grigorenko (1973) on peach trees, Tarhon et al. (1991) and El-Sanhoury (2003) on apricot and Soliman (2003) on young deciduous fruit trees. They found that, total and free water contents were significantly decreased under water soil deficit.

With respect to the effect of potassium fertilization, it was noticed that, total and free water content negatively affected by increasing the rate of potassium application up to $1 \mathrm{~kg} \mathrm{~K} \mathrm{~K}_{2} \mathrm{SO}_{4} /$ tree. These findings are in accordance with those of El-Sammak and Zayan (1988) who found that leaf moisture content of citrus was decreased by mineral fertilization due to increase dry matter percentage. The interaction was significant in both seasons, the control $\left(I_{1} \times K_{1}\right)$ treatment gave the highest values while, $\left(I_{3} X\right.$ $\mathrm{K}_{3}$ ) interaction recorded the least values.

\section{b. Bound water content and osmotic pressure:}

The obtained data of Table (7) revealed that, bound water content and osmotic pressure of the cell sap of peach leaves had been recorded a reversible behaviour to total and free water contents as influenced by irrigation and potassium treatments. It was significantly increased by reducing irrigation rate. The highest values recorded with deficit irrigation rate, $l_{3}(60 \%$ FC). This increment in bound water content and osmotic pressure under deficit of soil moisture could be attributed to reduction in vegetative growth which accumulates organic substances. These results are in line with those obtained by Grigorenko (1973), Zayan et al. (2002), El-Sanhoury (2003) and Soliman (2003) on different fruit trees. They found that, bound water content and osmotic pressure of cell sap significantly increased under water stress conditions.

With respect to the effect of potassium fertilizer, the data exhibited that, raising the level of potassium fertilizer from $K_{1}$ to $K_{3}$ significantly increased the percent of bound water and osmotic pressure of cell cap. The highest values belonged to high potassium fertilizater level $\mathrm{K}_{3}(1 \mathrm{~kg}$ $\mathrm{K}_{2} \mathrm{SO}_{4} /$ tree). These results might be due to direct effect of $\mathrm{K}$ ion and its role in increasing sugars (reducing and non reducing), polysaccharides and starch 
Mikhael, G. B.Y. et al.

as well as protein and other high molecular weight compounds which increase colloids substances in the plant cells (Gosev, 1966). Similar results were obtained by Koshnirenko (1967), El-Sammak et al. (1980) and El-Morsy (1980).

Table (7): Effect of irrigation and potassium fertilizer levels and their interaction on some water relations determinations on leaves of "Dessert Red" peach trees in 2008 and 2009 seasons.

\begin{tabular}{|c|c|c|c|c|c|c|c|c|c|}
\hline \multirow{2}{*}{\multicolumn{2}{|c|}{\begin{tabular}{|l|l|}
$|l|$ \\
Treatments \\
Irrigation & Fertilization \\
(I) levels & (K) levels
\end{tabular}}} & \multicolumn{2}{|c|}{$\begin{array}{l}\text { Total water } \\
\text { content } \%\end{array}$} & \multicolumn{2}{|c|}{$\begin{array}{l}\text { Free water } \\
\text { content } \%\end{array}$} & \multicolumn{2}{|c|}{$\begin{array}{c}\text { Bound water } \\
\text { content } \%\end{array}$} & \multicolumn{2}{|c|}{$\begin{array}{c}\text { Osmotic } \\
\text { pressure (atm) }\end{array}$} \\
\hline & & 2008 & 2009 & 2008 & 2009 & 2008 & 2009 & 2008 & 2009 \\
\hline \multirow{3}{*}{$l_{1}$} & $\mathrm{~K}_{1}$ & 65.22 & 65.57 & 49.15 & 49.35 & 16.07 & 16.22 & 14.74 & 15.05 \\
\hline & $\mathrm{K}_{2}$ & 64.31 & 64.06 & 47.38 & 47.33 & 16.93 & 16.73 & 16.33 & 16.71 \\
\hline & $K$ & 61.72 & 62.73 & 44.56 & 45.04 & 17.16 & 17.69 & 16.96 & 17.33 \\
\hline \multicolumn{2}{|l|}{ Average } & 63.75 & 64.12 & 47.03 & 47.24 & 16.72 & 16.88 & 16.01 & 16.36 \\
\hline \multirow{3}{*}{$l_{2}$} & $\mathrm{~K}_{1}$ & 63.85 & 63.85 & 46.64 & 46.59 & 17.21 & 17.26 & 15.40 & 16.33 \\
\hline & $\mathrm{K}_{2}$ & 59.17 & 61.45 & 41.62 & 43.16 & 17.55 & 18.29 & 17.21 & 17.58 \\
\hline & $\mathrm{K}_{3}$ & 58.25 & 59.38 & 39.53 & 40.51 & 18.75 & 18.87 & 17.95 & 18.09 \\
\hline \multicolumn{2}{|l|}{ Average } & 60.42 & 61.56 & 42.60 & 43.42 & 17.83 & 18.14 & 16.85 & 17.33 \\
\hline \multirow{3}{*}{$l_{3}$} & $\mathrm{~K}_{1}$ & 58.91 & 59.54 & 40.95 & 41.32 & 17.96 & 18.22 & 16.58 & 16.96 \\
\hline & $\mathrm{K}_{2}$ & 57.68 & 57.72 & 39.32 & 38.60 & 18.36 & 19.12 & 18.70 & 18.83 \\
\hline & $\mathrm{K}_{3}$ & 55.46 & 56.41 & 35.95 & 36.83 & 19.51 & 19.58 & 19.32 & 19.68 \\
\hline \multicolumn{2}{|l|}{ Average } & 57.35 & 57.89 & 38.74 & 38.92 & 18.61 & 18.97 & 18.20 & 18.49 \\
\hline \multirow{3}{*}{ Average } & $\mathrm{K}_{1}$ & 62.66 & 62.99 & 45.58 & 45.75 & 17.06 & 17.23 & 15.57 & 16.11 \\
\hline & $\mathrm{K}_{2}$ & 60.39 & 61.08 & 42.77 & 43.03 & 17.61 & 18.05 & 17.41 & 17.71 \\
\hline & $K_{3}$ & 58.48 & 59.51 & 40.01 & 40.79 & 18.46 & 18.71 & 18.08 & 18.37 \\
\hline \multirow{3}{*}{ L.S.D5\% } & I & 1.005 & 1.993 & 0.784 & 1.853 & 0.524 & 0.194 & 0.351 & 0.341 \\
\hline & K & 1.515 & 1.544 & 1.567 & 1.534 & 0.192 & 0.152 & 0.256 & 0.220 \\
\hline & $\mathrm{I} \times \mathrm{K}$ & 2.624 & 2.674 & 2.714 & 2.657 & 0.333 & 0.264 & 0.443 & 0.382 \\
\hline
\end{tabular}

$\mathrm{I}_{1}, \mathrm{I}_{2}$ and $\mathrm{I}_{3}=$ Irrigation at 80,70 and $60 \%$ of field capacity (FC), respectively

$\mathrm{K}_{1}, \mathrm{~K}_{2}$ and $\mathrm{K}_{3}=0.5,0.75$ and $1 \mathrm{~kg}$ potassium sulphate $\left(48 \% \mathrm{~K}_{2} \mathrm{O}\right)$ /tree, respectively.

The interaction was significant in both 2008 and 2009 seasons and the highest values of bound water and osmotic pressure recorded with $\left(l_{3} \mathrm{X}\right.$ $\left.K_{3}\right)$ interaction. Meanwhile, the least values belonged to the control $\left(I_{1} \times K_{1}\right)$ treatment. Other combination treatments gave intermediate values.

Conclusively, high levels of potassium application especially under moderate irrigation rate in $\left(\mathrm{I}_{2} \times \mathrm{K}_{3}\right)$ is considered the suitable combination treatment for improving water relations due to the effect of high $\mathrm{K}$ level in increasing percent of bound water and osmotic pressure of cell sap of leaf tissue which induced drought tolerance of peach trees under the condition of this study.

4. Yield:

Tabulated data in Table (8) revealed that, yield $(\mathrm{kg} / \mathrm{tree})$, yield efficiency $\left(\mathrm{kg} / \mathrm{cm}^{2} \mathrm{TCSA}\right)$ and total yield (ton/fed) of "Dessert Red" peach trees were gradually decreased by decreasing irrigation regime from 80 to $60 \%$ of field capacity. The maximum significant yield were achieved by trees of the high level of irrigation $80 \%$ FC in the first season followed by trees exposed to $70 \% \mathrm{FC}$, while, the minimum values were fruited under deficit irrigation level $60 \%$ FC. The trend was similar in the second season. These results could be attributed to the increment of the number of fruits/tree and 
the improvement of fruit weight. These results are in the same line of Seif and Abd El-Samad (2001) on peach, El-Gendy and Abd El-Meseih (2002) and Mikhael and Maddy (2007) on apple and Ibrahim and Abd El-Samad (2009) on pomegranate. They found that, a progressive reduction in fruit yield was observed in deficit irrigation treatment as compared to higher irrigation treatment. Furthermore, yield ( $\mathrm{kg} / \mathrm{tree}), \mathrm{YE}\left(\mathrm{kg} / \mathrm{cm}^{2} \mathrm{TCSA}\right)$ and total yield (ton/fed) were significantly influenced by potassium fertilization treatments. Using high level of potassium fertilizer $\left(\mathrm{K}_{3}\right) 1 \mathrm{~kg} \mathrm{~K} \mathrm{~K}_{2} \mathrm{SO}_{4} /$ tree produced the highest significant yield as compared to low and moderate levels $(0.5 \& 0.75$ $\mathrm{K}_{2} \mathrm{SO}_{4} /$ tree). These results might be due to the stimulation effect of potassium in increasing number of fruit per tree and average fruit weight. These results were supported by those obtained with Kilany and Kilany (1991) on apple trees,El-Morshedy (1997) on peach trees, Malaka et al. (1999) on apricot trees and El-Abd (2005) on citrus trees.

Table (8): Effect of irrigation and potassium fertilizer levels and their interaction on yield and field water use efficiency (FWUE) of "Dessert Red" peach trees in 2008 and 2009 seasons.

\begin{tabular}{|c|c|c|c|c|c|c|c|c|c|}
\hline \multirow{3}{*}{\multicolumn{2}{|c|}{\begin{tabular}{|l|l|} 
Treatments \\
Irrigation & Fertilization \\
(I) levels & (K) levels \\
\end{tabular}}} & \multicolumn{6}{|c|}{ Yield } & \multirow{2}{*}{\multicolumn{2}{|c|}{$\begin{array}{c}\text { Field Water use } \\
\text { efficiency } \\
(\mathrm{kg} / \mathrm{fed}) \mathrm{m}^{3} \text { water }\end{array}$}} \\
\hline & & \multicolumn{2}{|c|}{ kg/tree } & \multicolumn{2}{|c|}{$\mathrm{YE}\left(\mathrm{kg} / \mathrm{m}^{2} \mathrm{TCSA}\right)$} & \multicolumn{2}{|c|}{ ton/fed } & & \\
\hline & & 2008 & 2009 & 2008 & 2009 & 2008 & 2009 & 2008 & 2009 \\
\hline \multirow{3}{*}{$l_{1}$} & $\mathrm{~K}_{1}$ & 26.29 & 27.14 & 0.206 & 0.183 & 6.84 & 7.05 & 1.66 & 1.71 \\
\hline & $\mathrm{K}_{2}$ & 33.91 & 35.70 & 0.255 & 0.227 & 8.82 & 9.37 & 2.14 & 2.27 \\
\hline & $\mathrm{K}_{3}$ & 37.61 & 38.94 & 0.275 & 0.228 & 9.78 & 10.12 & 2.37 & 2.45 \\
\hline \multicolumn{2}{|l|}{ Average } & 32.60 & 33.93 & 0.245 & 0.213 & 8.48 & 8.85 & 2.06 & 2.14 \\
\hline \multirow{3}{*}{$l_{2}$} & $\mathrm{~K}_{1}$ & 24.11 & 24.97 & 0.193 & 0.176 & 6.27 & 6.49 & 1.80 & 1.86 \\
\hline & $\mathrm{K}_{2}$ & 29.56 & 26.89 & 0.249 & 0.198 & 7.69 & 7.92 & 2.21 & 2.27 \\
\hline & $\mathrm{K}_{3}$ & 37.44 & 38.13 & 0.271 & 0.226 & 9.73 & 9.91 & 2.79 & 2.85 \\
\hline \multicolumn{2}{|c|}{ Average } & 30.37 & 30.00 & 0.238 & 0.200 & 7.90 & 8.11 & 2.27 & 2.33 \\
\hline \multirow{3}{*}{$l_{3}$} & $\mathrm{~K}_{1}$ & 23.07 & 22.45 & 0.194 & 0.172 & 6.00 & 5.84 & 1.94 & 1.89 \\
\hline & $\mathrm{K}_{2}$ & 24.80 & 24.23 & 0.207 & 0.189 & 6.36 & 6.61 & 2.05 & 2.14 \\
\hline & $\mathrm{K}_{3}$ & 28.94 & 30.18 & 0.240 & 0.218 & 7.52 & 7.85 & 2.43 & 2.54 \\
\hline \multicolumn{2}{|l|}{ Average } & 25.60 & 25.62 & 0.214 & 0.193 & 6.63 & 6.77 & 2.14 & 2.19 \\
\hline \multirow{3}{*}{ Average } & $\mathrm{K}_{1}$ & 24.49 & 24.85 & 0.198 & 0.177 & 6.37 & 6.46 & 1.80 & 1.82 \\
\hline & $\mathrm{K}_{2}$ & 29.42 & 28.94 & 0.237 & 0.205 & 7.62 & 7.97 & 2.13 & 2.23 \\
\hline & $\mathrm{K}_{3}$ & 34.66 & 35.75 & 0.262 & 0.224 & 9.01 & 9.29 & 2.53 & 2.61 \\
\hline \multirow{3}{*}{ L.S.D5\% } & I & 1.114 & 1.496 & 0.0131 & 0.0134 & 0.290 & 0.442 & 0.083 & 0.110 \\
\hline & $\mathrm{K}$ & 1.508 & 1.359 & 0.0103 & 0.0107 & 0.391 & 0.366 & 0.117 & 0.092 \\
\hline & $\mathrm{I} \times \mathrm{K}$ & 2.613 & 2.354 & 0.0178 & 0.0185 & 0.677 & 0.634 & 0.203 & 0.159 \\
\hline
\end{tabular}

$\mathrm{I}_{1}, \mathrm{I}_{2}$ and $\mathrm{I}_{3}=$ Irrigation at 80,70 and $60 \%$ of field capacity (FC), respectively

$\mathrm{K}_{1}, \mathrm{~K}_{2}$ and $\mathrm{K}_{3}=0.5,0.75$ and $1 \mathrm{~kg}$ potassium sulphate $\left(48 \% \mathrm{~K}_{2} \mathrm{O}\right)$ /tree, respectively.

Data in Table (8) clarify that, the interaction was significant and the highest yield ( $\mathrm{kg} / \mathrm{tree}$ ) and (ton/fed), as well as, yield efficiency $\left(\mathrm{kg} / \mathrm{cm}^{2}\right.$ TCSA) were obtained by using high and moderate irrigation regimes $(80 \%$ and $70 \% \mathrm{FC}$ ) under application of high potassium fertilizer level (1 kg $\mathrm{K}_{2} \mathrm{SO}_{4} /$ tree $)$ in $\left(\mathrm{I}_{1} \times \mathrm{K}_{3}\right)$ and $\left(\mathrm{I}_{2} \times \mathrm{K}_{3}\right)$ combination treatments without significant differences between them in both seasons, while trees received low level potassium $\left(0.5 \mathrm{~kg} \mathrm{~K}_{2} \mathrm{SO}_{4}\right)$ under deficit irrigation regime $(60 \% \mathrm{FC})$ in $\left(\mathrm{I}_{3} \times \mathrm{K}_{1}\right)$ treatment produced lower yield. 
Conclusively $\left(\mathrm{I}_{2} \times \mathrm{K}_{3}\right)$ was considered the suitable combination treatments for improving productivity of "Dessert Red" peach trees (37.44 and $38.13 \mathrm{~kg} / \mathrm{tree}$ ) in 2008 and 2009 seasons, respectively. Furthermore, saving applied water by using moderate irrigation regime.

\section{Field water use efficiency (FWUE) $\left(\mathrm{kg} / \mathrm{m}^{3}\right)$}

Field water use efficiency values are used to evaluate the effectiveness of irrigation and fertilization practices for maximum utilization of water supplies. Data presented in Table (8) showed that, field water use efficiency (FWUE) of peach trees significantly affected by irrigation regimes, potassium fertilization and their interaction. The highest significant values of FWUE were obtained from trees irrigated at $70 \%$ FC (moderate irrigation regime) in both seasons followed in descending order by those irrigated at $60 \%$ and $80 \%$ C.F. Similar results were obtained by Fathi (1994) on "Le Conte" pear, Abd El-Messeih and El-Gendy (2004b) on "Cannino: apricot, Mikhael and Mady (2007) on "Anna" apple and Ibrahim and Abd El-Samad (2009) on "Manfalouty" pomegranate. They indicated a gradual decrease in WUE values due to increase the amount of applied water.

Concerning to potassium application, the obtained results revealed that, adding high level, $1 \mathrm{~kg} \mathrm{~K} \mathrm{~K}_{2} \mathrm{SO}_{4} /$ tree $\left(\mathrm{K}_{3}\right)$ gave the highest significant values of field water use efficiency (FWUE) followed in discendingly order by $0.75 \mathrm{~K}_{2} \mathrm{SO}_{4} /$ tree $\left(\mathrm{K}_{2}\right)$. On the other hand, trees received $0.5 \mathrm{~kg} \mathrm{~K}_{2} \mathrm{SO}_{4} /$ tree $\left(\mathrm{K}_{1}\right)$ had the lowest significant value FWUE in both seasons.

Regarding, the interaction between irrigation regimes and potassium fertilizer levels $(\mathrm{I} \times \mathrm{K})$ was significant in both seasons and the highest FWUE values always belonged to trees irrigated at $70 \% \mathrm{FC}\left(\mathrm{I}_{2}\right)$ which received $1 \mathrm{~kg}$ $\mathrm{K}_{2} \mathrm{SO}_{4}\left(\mathrm{~K}_{3}\right)$ in $\left(\mathrm{I}_{2} \times \mathrm{K}_{3}\right)$ combination treatment with $\left(2.79 \& 2.85 \mathrm{~kg}\right.$ fruit $/ \mathrm{m}^{3}$ water) in 2008 and 2009 seasons, respectively. While, the lowest values came from the control $\left(I_{1} \times K_{1}\right)$. However, other combination treatments gave intermediate values. Thus, $\left(\mathrm{I}_{2} \times \mathrm{K}_{3}\right)$ is considered the best combination treatment for improving fruit production and increasing field water use efficiency (FWUE) of "Dessert Red" peach trees under the condition of this study.

\section{Physical and chemical fruit properties:}

\section{a. Fruit weight and dimensions:}

Data presented in Table (8) indicated that, fruit weight (g), length and diameter $(\mathrm{cm})$ were significantly decreased by reducing irrigation regime and the smallest fruit were produced under deficit irrigation regime $60 \% \mathrm{FC}\left(\mathrm{I}_{3}\right)$. The reduction in fruit weight and size under deficit soil moisture content could be due to reduce fruit cell enlargement through reduce fruit trugor early in the season and to decrease cell water content (Li et al., 1989). Furthermore, Behbudian et al. (1994) pointed out that, reduce fruit size under water stress might be due to less assimilate availability through decrease net photosynthesis rate $(\mathrm{Pn})$. These results coincided with those reported by Chalmers et al. (1985) and Genard and Huguet (1995) on peach, Atkinson et al. (2000) and Mikhael and Mady (2007) on apple. They mentioned that, fruit weight and size were markedly increased by irrigation.

Concerning to the influence of potassium fertilization, the obtained data revealed that, increasing the rate of potassium significantly increased 
fruit weight and its dimensions. The heaviest and largest "Dessert Red" peach fruit was produced by soil application with high level of potassium $1 \mathrm{~kg}$ $\mathrm{K}_{2} \mathrm{SO}_{4}\left(\mathrm{~K}_{3}\right)$ in the first season. This trend was also true in the second season. The positive effect of potassium in improving fruit weight and size could be attributed to its important role in promoting and enhancing the metabolic process during uptake, root activation, regular water balance and translocation compounds which in turn increase the growth and reflects on yield and fruit quality (Nijjar, 1985). Such findings are in harmony with those reported by Kilany and Kilany (1991), Mikhael (1994), Abo Ogiela (2006) and Gowda (2007). However, the interaction was significant in both seasons and maximum fruit weight, length and diameter were produced with $\left(I_{1} \times K_{3}\right)$ and $\left(\mathrm{I}_{2} \times \mathrm{K}_{3}\right)$ treatments without significant differences between them in both seasons. Meanwhile, the minimum values came from $\left(\mathrm{I}_{3} \times \mathrm{K}_{1}\right)$ treatment.

\section{Fruit firmness:}

With respect to fruit firmness $\left(\mathrm{lb} / \mathrm{in}^{2}\right)$, data tabulated in Table (9) indicated that, increasing irrigation and potassium fertilizer levels led to decrease fruit firmness. The differences were significant in both seasons. This reduction in fruit firmness may be due to the increase in fruit size and its water content. However, the interaction $(\mathrm{I} \times \mathrm{K})$ was significant in the two seasons of study. The highest values of fruit firmness were recorded with $\left(I_{3} X\right.$ $\left.\mathrm{K}_{1}\right)$ interaction. Meanwhile, $\left(\mathrm{I}_{1} \times \mathrm{K}_{3}\right)$ treatment produced less fruit firmness.

Table (9): Effect of irrigation and potassium fertilizer levels and their interaction on physical and chemical properties" of "Dessert Red" peach fruits in 2008 and 2009 seasons.

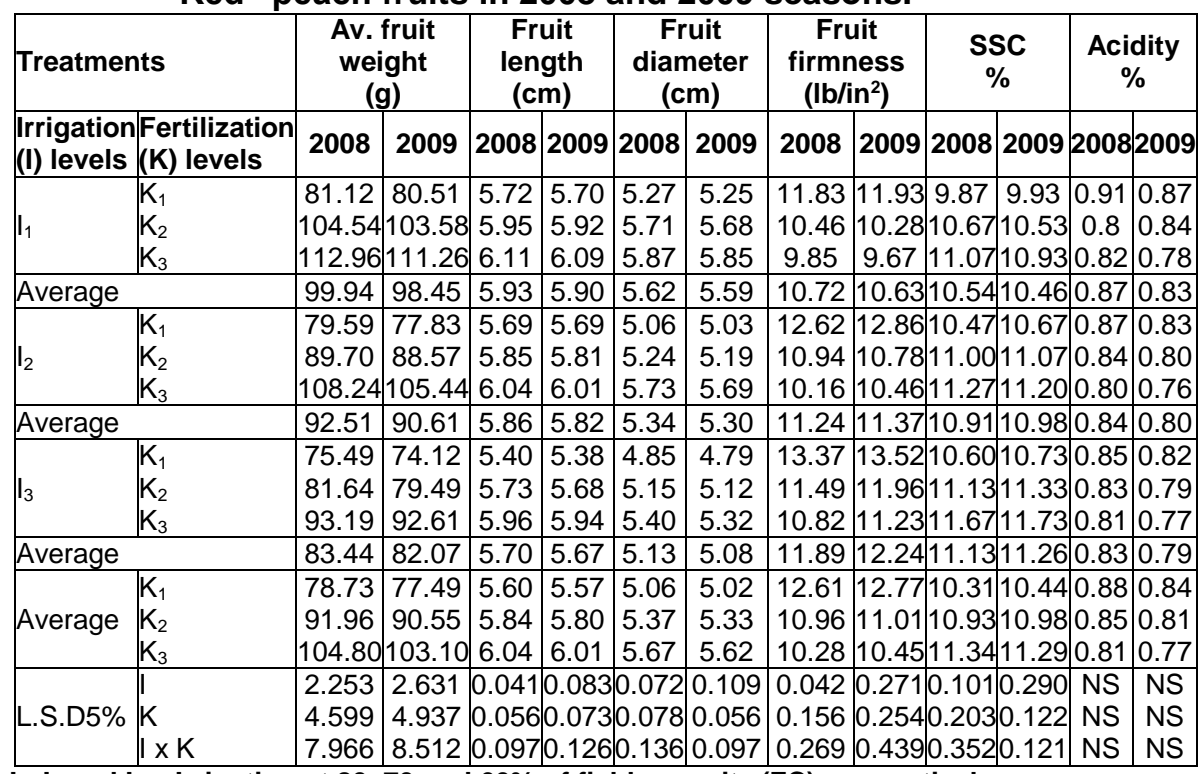

$\mathrm{I}_{1}, \mathrm{I}_{2}$ and $\mathrm{I}_{3}=$ Irrigation at 80,70 and $60 \%$ of field capacity (FC), respectively

$\mathrm{K}_{1}, \mathrm{~K}_{2}$ and $\mathrm{K}_{3}=0.5,0.75$ and $1 \mathrm{~kg}$ potassium sulphate $\left(48 \% \mathrm{~K}_{2} \mathrm{O}\right)$ /tree, respectively.

* At harvest time (May, 18 ${ }^{\text {th }}$ and May $16^{\text {th }}$ ) in 2008 and 2009 seasons, respectively. 
These results are in harmony with those obtained by Abd El-Messeih and ElGendy (2004a) and Mikhael and Mady (2007) who reported that deficit irrigation regime induced significantly higher fruit firmness. In addition, Mikhael (1994) mentioned that, the values of fruit firmness of "Anna" apple were decreased by increasing potassium fertilizer level. Otherwise, ElMorshedy (1997) indicated that, there were positive correlation between K application and peach fruit firmness.

\section{c. Soluble solids content (SSC) and total acidity percentage:}

Data of table (9) showed that, there was a gradual increase in fruit SSC associated with the decrease in irrigation regime from $80 \%$ to $60 \%$ FC in both seasons. These results could be attributed to advance fruit maturity under drought condition. Similar results were reported by Shahein et al. (2002b) on "Anna" apple trees. Who indicated that, fruit from the deficit irrigation treatment had higher soluble solids content (SSC). On the contrary, AbdEl-Masseih and El-Gendy (2004a) and Mikhael and Mady (2007) noticed that, increasing irrigation rate produced high fruit SSC percent. It could be observed that, adding potassium fertilizer with high level $\left(1 \mathrm{~kg} \mathrm{~K}_{2} \mathrm{SO}_{4} /\right.$ tree $)$ was superior for raising SSC value. These results may be due to the effect of $\mathrm{K}$ on enhancing fruit maturity (Zayan et al., 2006). The obtained results herein are in line with those reported by Mikhael (1994) and Gowda (2007). However, the interaction was significant and the highest SSC values recorded with $\left(\mathrm{I}_{2} \times \mathrm{K}_{3}\right)$ and $\left(\mathrm{I}_{3} \times \mathrm{K}_{3}\right)$ treatment while, the least values obtained from the control $\left(l_{1} \times K_{1}\right)$ treatment in both seasons.

From the above mentioned results, it could be concluded that, total acidity was not significantly affected by all irrigation and potassium fertilization treatments, as well as, their interaction in $1^{\text {st }}$ and $2^{\text {nd }}$ seasons. Similar findings were also achieved by Zayan et al. (2006) on potassium fertilization of grapevines and Mikhael and Mady (2007) on irrigation of apple trees.

\section{d. Fruit colour:}

With regard to the effect of irrigation regimes, potassium fertilizer levels and their interaction on red colour \% and skin anthocyanin content $\mu \mathrm{g} / \mathrm{cm}^{2}$ of "Dessert Red" peach fruit, the data of both seasons illustrated in Fig. (3 and 4) showed that, the percent of red colour and the values of anthocyanin content in peach fruit skin were increased by reducing irrigation regime and increasing potassium fertilization level. However, the interaction was significant in both seasons and the highest values were achieved by $\left(I_{2} \mathrm{X}\right.$

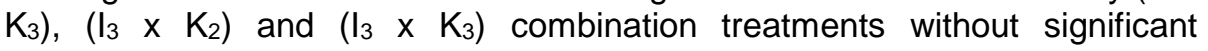
differences among them in both seasons. Meanwhile, the control $\left(\mathrm{l}_{1} \times \mathrm{K}_{1}\right)$ treatment recorded the lowest values. These findings was supported by those of Shahien et al. (2002b) on "Anna" apple who found that tree grown under deficit irrigation rate had significantly, the highest concentration of the anthocyanin in fruit skin. However, Mansour et al. (1986) noticed that, soil application with potassium sulphate improved colour of "Mit Ghamr" peach fruit. In addition, Mikhael (1994) indicated that, potassium application increased colour \% and anthocyanin concentration in fruit skin of "Anna" apple due to the effect on potassium in advancing fruit maturity and anthiocyanin biosynthesis. 


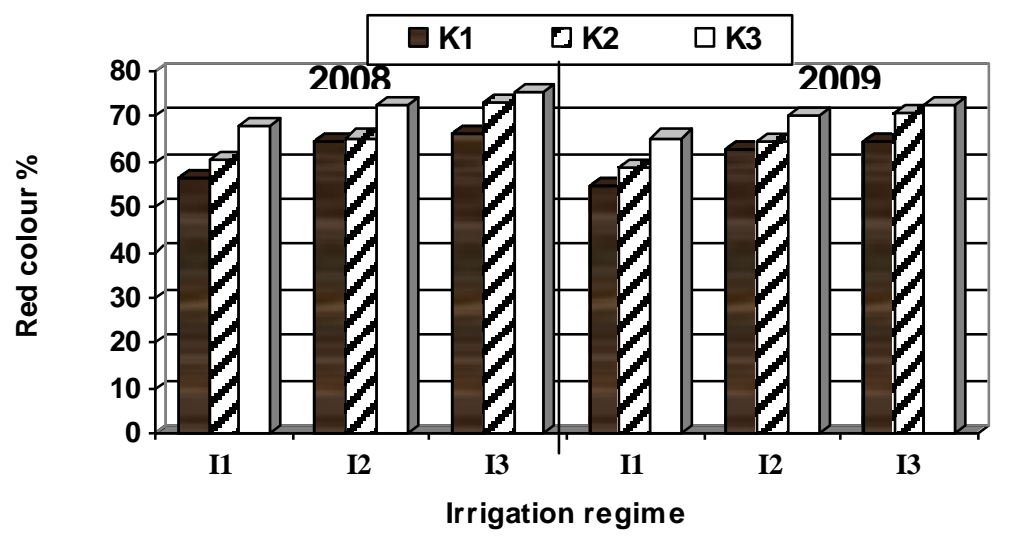

Fig. (3): Effect of irrigation and potassium fertilizer levels on skin red colour (\%) of "Dessert Red" peach fruits in 2008 and 2009 seasons.

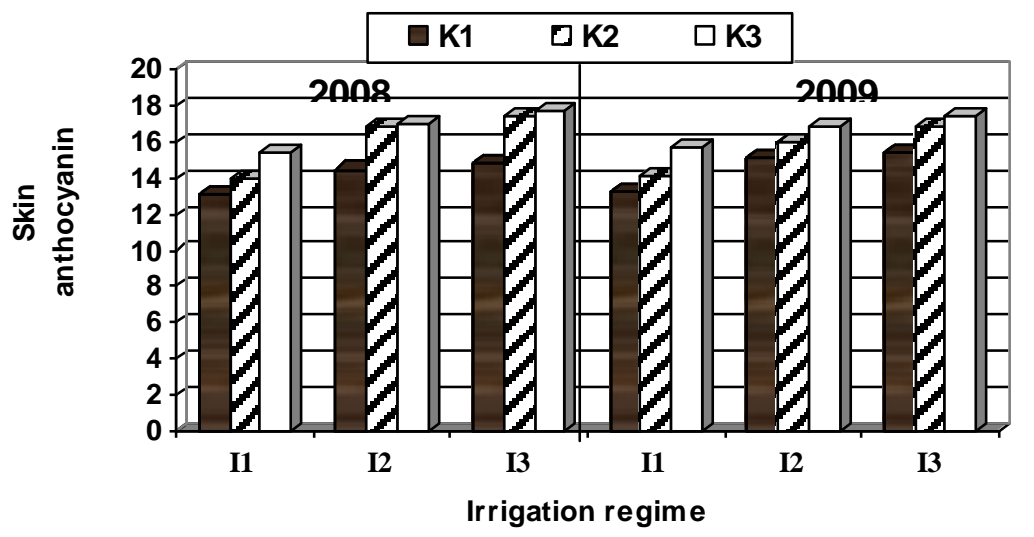

Fig. (4): Effect of irrigation and potassium fertilizer levels on skin anthocyanin content $\left(\mu \mathrm{g} / \mathrm{cm}^{2}\right)$ of "Dessert Red" peach fruits in 2008 and 2009 seasons.

Therefore, this study recommends "Dessert Red" peach growers on clay soil to be irrigated at $70 \%$ F.C. (moderate irrigation rate) with applying 1 $\mathrm{kg} \mathrm{K}_{2} \mathrm{SO}_{4} /$ tree (high potassium level in $\left(\mathrm{I}_{2} \times \mathrm{K}_{3}\right)$ which considered the best combination treatment. This treatment not only stimulated vegetative growth, improved nutritional status and water relations but also, produced maximum yield with high quality especially weight, size, colour and SSC\%. Beside, saved irrigation water by decreasing the amount of water applied and raising field water sue efficiency (FWUE) $\mathrm{kg}$ fruit $/ \mathrm{m}^{3}$. 


\section{REFERENCES}

Abd El-Messieh, W.M. and R.W. El-Gendny (2004a). Effect of different trickle irrigation levels based on soil metric potential on: 1-Vegetative growth and yield of "Canino" apricot trees planted in sandy soils. Alex. Sci. Exch., 25(3): 465-480.

Abd El-Messieh, W.M. and R.W. El-Gendy (2004b). Effect of different trickle irrigation levels based on soil matric potential on: 2-leaf chemical composition and active rooting depth of "Canino" apricot trees planted in sandy soils. Alex. Sci., Exch., 25(3): 481-495.

Abo Ogiela, H.M. (2006). Response of guava trees to some pruning treatments and foliar application of potassium. M.Sc. Thesis, Fac. Agric., Kafr El-Sheikh, Tanta Univ., Egypt.

A.O.A.C. (Association of Official Agriculture Chemists) (1990). Official methods of analysis. $15^{\text {th }}$ Ed., Washington D.C., USA.

Atkinson, C.J.; A.D. Webster; S.P. Vaughan; L. Taylor and G. Kingswell (2000). Interaction between root restriction, irrigation rootstock treatments on "Queen Cox" apple trees: Effect of soil and plant water relation. J. Hort. Biotech., 75(4): 376-382.

Bates, L.S.; R.P. Waldren and L.D. Teare (1973).. Rapid determination of free proline for water stress studies. Plant and Soil, 39: 205-207.

Behboudian, M.H.; G.S. Lawes and K.M. Griffiths (1994). The influence of water deficit on water relation, photosynthesis and fruit growth in Asian pear (Pyrus serotina Rehd.). Scientia Horticulture, 60: 84-99.

Berman, M.E. and T.M. Dejony (1996). Water stress and crop load effects on fruit fresh and dry weights in peach (Prunus persica). Tree Physiol., 16: 859-864.

Black, C.A. (1983). Methods of soil analysis Part I and II. Amer. Agron. Inc., Publ. Madison, Wisconsin, USA.

Boland, A.M.; P.H. Jerie; P.D. Mithcell; I. Goodwin and D.J. Connor (2000). Long-term effects of restricted root volume and regulated deficit irrigation on peach. I. Growth and mineral nutrition. J. Amer. Soc. Hort. Sci., 125: 135-142.

Chalmers, D.J.; P.D. Michell and P.H. Jerie (1985). The relation between irrigation, growth and productivity of peach trees. Acta Hort. 173: 283288.

Cummings, G.A. (1980). K fertilization increases yield and quality of peaches. Better Crips in Plant Food, 64(Autumn): 20-21.

El-Abd, A.A. (2005). Influence of fertilization and irrigation on "Washington Navel" orange orchards. Ph.D. Thesis, Fac. Agric., Kafr El-Sheikh, Tanta Univ., Egypt.

El-Gendy, R.W. and W.M. Abd El-Messeih (2002). Water consumptive and apple trees productivity as affected by soil water suction and irrigation scheduling. Menufiya J. Agric. Res., 27(2): 391-405.

El-Morshedy, F.A. (1997). Studies on fertilization regimes of peach. J. Agric. Res. Tanta Univ., 23(4); 395-412. 
El-Morsy, A.A. (1980). Effect of fertilization on water relations of citrus. M.Sc. Thesis, Fac. Agric., Kafrelsheikh, Tanta Univ., Egypt.

El-Sammak, A.F. and M.A. Zayan (1988). Response of Baladi mandarin trees under long irrigation period to mineral fertilization. J. Agric. Res. Tanta Univ., 14(2): 906-923.

El-Sammak, A.F.; E.M. Mohamed and A.A. El-Morsy (1980). Effect of fertilization on water relations and growth of young trees of Washington Navel orange. J. Agric. Res. Tanta Univ. 6(2): 182-193.

El-Sanhoury, A.M. (2003). Studied on drought tolerance of three apricot varieties. M.Sc. Thesis, Fac. Agric., Kafrelsheikh, Tanta Univ., Egypt.

Fathi, M.A.; B.A. Shahin and G.I. Eliws (1999). Screening of some deciduous fruit rootstocks for relative drought resistance. J. Agric. Sci., Mansoura Univ., 24(6): 351-360.

Foster, D.S. and T.S. Cornelia (1967). Colorimetric methods of analysis. D. Van Nestrant Company Inc., pp. 551-552.

Genard, M. and J.G. Huguet (1995). Modeling the response of peach fruit growth to water stress. Tree physiology 16: 407-415.

Gosev, N.A. (1960). Some methods in study plant water relations. Press of Soviet Society for Potential Science, USSR, p. 60.

Gosev, N.A. (1966). Physiology of water metabolism. Kazan Univ. Press, USSR, pp. 14-16.

Gowda, A.M. (2007). Effect of some organic manures and potassium addition on growth, yield and fruit quality of Sultani fig trees. J. Agric. Sci. Mansoura Univ., 32(2): 1273-1291.

Grigorenko, N.V. (1973). The water regime of peach leaves on different rootstocks in relation to drought resistance. Byulleten Gosudarstvennogo-Nixitskogo-Botanicheskogo-Sada No. 3(22): 52-55.

Hanks, R.D. (1983). Yield and water use relationships. Amer. Soc. Agron., 13: 393-411.

Hunt, R. (1989). Plant growth curves. Textbook, Printed (In Arabic), Baghdad, Iraq, pp. 25-76.

Hussein, S.M.M. (1998). Influence of irrigation levels on the growth mineral content and fruit quality of "Anna" apple. M.Sc. Thesis, Fac. Agric., Cairo Univ., Egypt.

Ibrahim, A.M. and G.A. Abd El-Samad (2009). Effect of different irrigation regimes and partial substitution of $\mathrm{N}$-mineral by organic manures on water use, growth and productivity of pomegranate trees. Europ. J. Sci. Res., 38(2): 199-218.

Jackson, N.L. (1967). Soil chemical analysis. Prentice Hall Inc., Englewood, Cliffs, N.S.

Jackson, N.L. and A. Ulich (1959). Analytical method for use in plant analysis. Coll of Agric. Exp. State. Bull. 766, p. 25.

Keleg, F.M.; El-Gazzar and M.A. Zahran (1977). Response of Jordan almond trees to soil and foliar application of nitrogen, phosphorus and potassium. Alex. J. Agric. Res. 25(3): 473-482. 
Kassem, A.A. (1991). The effect of nitrogen, phosphorus and potassium fertilization on leaf and fruit mineral content, yield and fruit quality of Barkher apple trees and physiological changes of the fruit during cold storage. Ph.D. Thesis, Alex. Univ., Egypt.

Kilany, A.E. and O.A. Kilany (1991). Effect of potassium and boron nutrients on growth, yield and fruit quality of "Anna" apple trees. Bull. Fac. Agric., Cairo Univ., 42(2): 415-428.

Klute, A. (1986). Methods of soil analysis part $1-2^{\text {nd }}$ ed. ASA and SSSA, Madison.

Koshnirinko, M.D. (1967). Water system and drought resistance of fruit trees. IZV. Kora, Maldovia, Kishiniov.

Koshnirinko, M.D.; A.A.A. Gonsharova and E.M. Bonder (1970). Methods of study water relation and drought resistance of fruit trees. Acad. Sci. Press, Maldovia, USSR, pp. 53-61.

Li, S.H.; J.G. Huguet; P.G. Schoch and P. Orlando (1989). Response of peach tree growth and cropping to soil water deficit at various phonological stages of fruit development. J. Hort. Sci. 64: 541-552.

Malaka, N.M.M.; M. Saleh and L.F. Hagagg (1999). Effect of potash fertilization on yield and fruit quality of "Amar" apricot trees. $3^{\text {rd }}$ Conf. Agric. Dev. Res. Fac. Agric., Ain Shams Univ., Cairo, Egypt, Dec. 2224, Annuals Agric. Sci., Special Issue, pp. 597-604.

Mansour, N.M.; M. El-Gebealy and A. Shaltout (1986). Effect of potassium sulphate and fruit characters of peach trees. Egypt. J. Hort. Sci. 13(1): 35-42.

Mengel, K. and E.A. Kirkby (1978). Principles of plant nutrition. Int. Potash Inst., Berne Kalyani Publishers, New Delhi; Ludhignu Chap., 7: 140159.

Mengle, K. and E.A. Kirkby (1982). Principal of plant nutrition. Bern. Switzerland. Int. Potash. Inst., p. 520.

Michael, A.M. (1978). Irrigation theory and practice Vikus Publishing House, PVT Ltd, New Delhi, India.

Mikhael, G.B. (1994). Studied on "Anna" apple fertilization. M.Sc. Thesis, Fac. Agric., Kafr Elsheikh, Tanta Univ., Egypt.

Mikhael, G.B. (2007). Effect of some drip irrigation and mulching treatment on: 1- Vegetative growth and nutritional status of "Anna" apple trees grown in new reclaimed soils. Minufiya J. Agric. Res., 32(4): 11551174.

Mikhael, G.B. and A.A. Mady (2007). Effect of some drip irrigation and mulching treatments on: yield, fruit quality and water use efficiency of "Anna" apple trees grown in new reclaimed soils. Minufiya J. Agric. Res., 32(4): 1175-1191.

Mills, T.M.; M.H. Behboudian and B.E. Clothier (1996). Water relations growth and the composition of "Braeburn" apple fruit under deficit irrigation. J. Amer. Soc. Hort. Sci. 121(2): 261-291.

MALR (Ministry of Agriculture and Land Reclamation) (2008). Agricultural Economics. Annual Report, Cairo, Egypt.

Moawad, A.E. (2008). Production of "LeCont" pear trees as affected by some agricultural treatments. M.Sc. Thesis, Fac., Kafrelsheikh Univ., Egypt. 
Mpelasoka, B.S.; M.H. Behboudian and T.M. Mills (2001). Water relations, photosynthesis, growth, yield and fruit size of "Braeburn" apple: response to deficit irrigation and to crop load. J. of Hort. Sci., \& Biotechnology, 76(2): 150-156.

Murquard, R.D. and J.L. Timpton (1987). Relationship between extractable chlorophyll and an in situ method to estimate leaf green. Hort. Sci. 22(6): 1327.

Nandwal, A.S.; B.S. Kundu; A. Hooda and M.S. Kuhad (1996). Water relations and nitrogen fixation in potassium fed Vigna radiata nodules. J. Biological Plantarum 38(4): 629-632.

Naor, A.; H. Hupert; Y.Greenblat; M. Peres; A. Kaufman and I. Klein (2001). The response of nectarine fruit size and midday stem water potential to irrigation level in stage III and crop load. J. Amer.Soc. Hort. Sci. 126(1): 140-143.

Nijjar, G.S. (1985). Nutrition of fruit trees. Kaalyani Publishers, New Delhi, India, pp. 10-52.

Ranganna, S. (1979). Manual analysis of fruit and vegetable products. New Delhi, India, pp. 88-91.

Seif, A.S. and G.A. Abd El-Samad (2001). Effect of irrigation deficit on vegetative growth, productivity, water use efficiency and root length density of three peach cultivars. Annals of Agric. Sci., Moshtohor, 39: 2307-3223.

Shahein, A.H.; M.B. El-Sobrout; M.M. Yehia and W.M. Abd El-Messeih (2002a). Effect drip irrigation and nitrogen fertilization on: 1-The vegetative growth and active rooting depth of "Anna" apple trees grown in new reclaimed soils. J. Agric. Sci. Mansoura Univ., 27(4): 23952409.

Shahein, A.H.; M.B. El-Subrout; M.M. Yehia and W.M. Abd El-Messeih (2002b). Effect of drip irrigation and nitrogen fertilization on: III. The yield, fruit quality and saving water of "Anna" apple trees grown in new reclaimed soils. J. Agric. Sci. Mansoura Univ., 27(4): 2431-2450.

Snedecor, G.W. and W.G. Cochran (1990). Statistical methods, $7^{\text {th }}$ Ed. The lowa State Univ. Press, Ames. lowa, USA, p. 593.

Soliman, M.A. (2003). Effect of foliar spray nutrients on water relationships of some young deciduous fruit trees. M.Sc. Thesis, Fac. Agric., Kafrelsheikh, Tanta Univ., Egypt.

Tarhon, P.; I. Sirbu; E. Rusangavna and N. Grous (1991). Water regime and nitrogen metabolism in 1-year old seedlings of some stone fruits and their drought resistance. Bull. Acad. de-stina-a-Repub-Moldova-Stiinte Biologica-Chinice No. 4: 11-16.

Yoshida, S.; D.A. Forno; J.H. Cock and K.A. Gomez (1972). Laboratory manual for physiological studies of rice. The International Rice Research Institute Los Banos, Philippines.

Zayan, M.A.; A.F. El-Sammak; S.M. Zeerban and A.R. El-Sherif (2002). Physiological responses of some grapevines varieties to drought conditions. $2^{\text {nd }}$ Inter. Conf. Hort. Sci., Kafr El-Sheikh, Tanta Univ., Egypt, pp. 782-795. 
Zayan, M.A.; M.M. El-Mogy and G.B. Mikhael (2006). Vegatative growth and yield of Thompson seedless grapevines as affected by NPK fertilization and application of some soil amendments agents. J. Agric. Sci. Mansoura Univ., 31(4): 2239-2252.

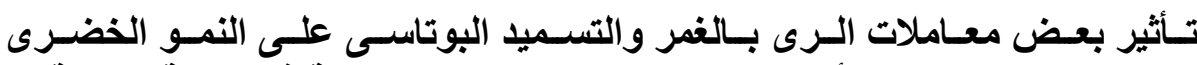

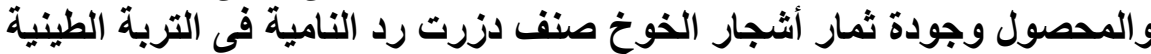

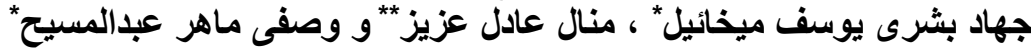

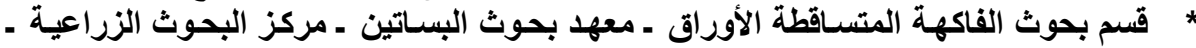

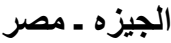
* معهد بحوث الأراضى والمياه والبيئة ـ مركز البحوث الزراعية ـ الجيزه ـ مصر

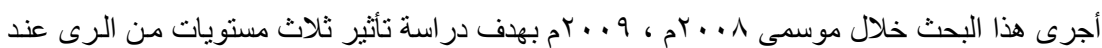

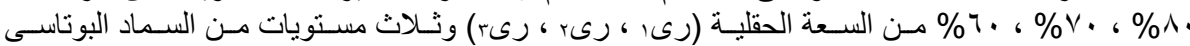

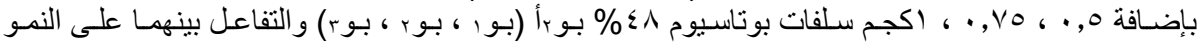

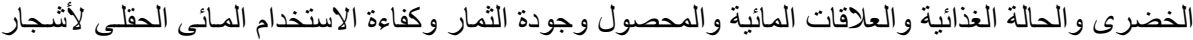

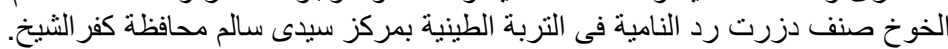

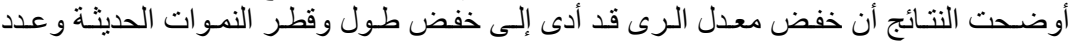

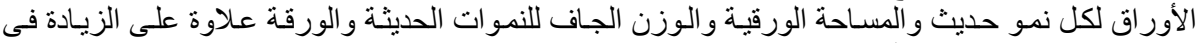

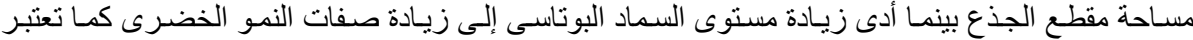

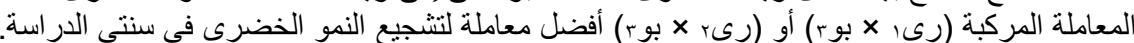

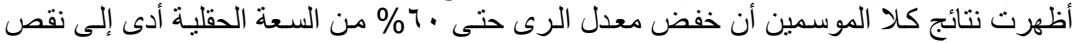

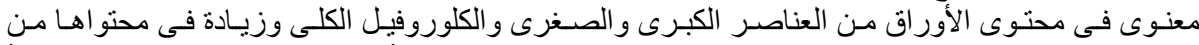

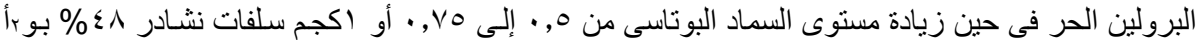

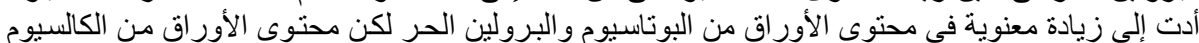

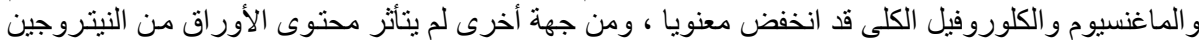
و الفوسفور والحديد والمنجنيز و الزنلك بزيادة مستوى السماد البوت تاسىى.

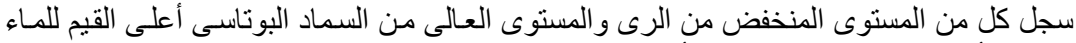

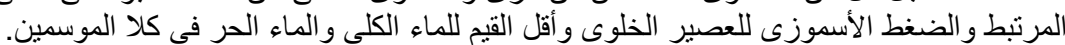

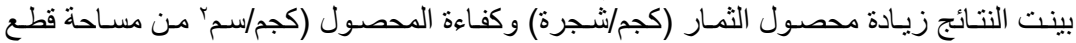

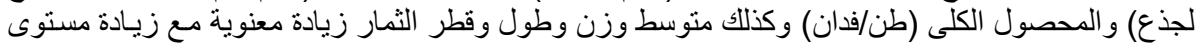

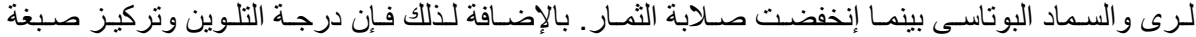

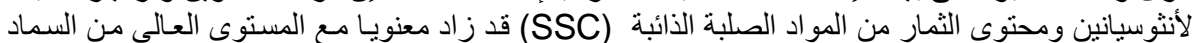

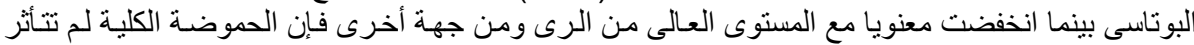

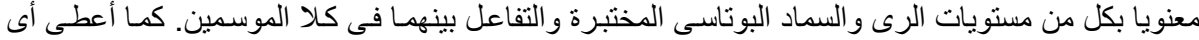

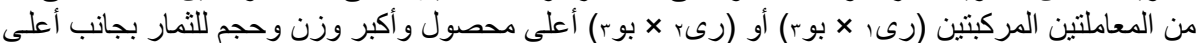

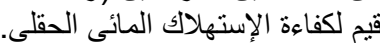

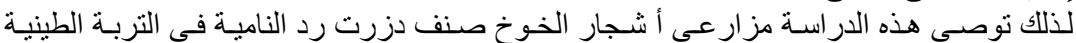



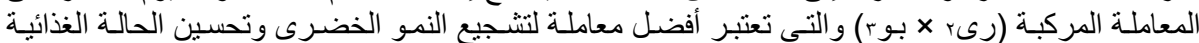

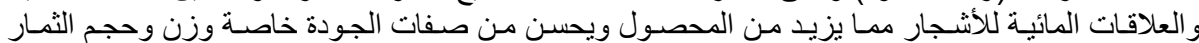

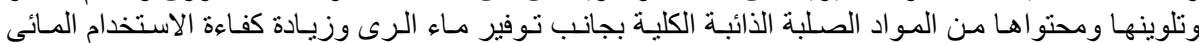

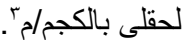

كلية الزراعة - جامعة المنصورة كلية الزراعة - جامعة كفر الثيخ 